\title{
Are CEOs Born Leaders? Lessons from Traits of a Million Individuals
}

\section{Citation}

Adams, Renée, Matti Keloharju, and Samuli Knüpfer. "Are CEOs Born Leaders? Lessons from Traits of a Million Individuals." Harvard Business School Working Paper, No. 16-044, October 2015.

\section{Permanent link}

http://nrs.harvard.edu/urn-3:HUL.InstRepos:23490131

\section{Terms of Use}

This article was downloaded from Harvard University's DASH repository, and is made available under the terms and conditions applicable to Other Posted Material, as set forth at http:// nrs.harvard.edu/urn-3:HUL.InstRepos:dash.current.terms-of-use\#LAA

\section{Share Your Story}

The Harvard community has made this article openly available.

Please share how this access benefits you. Submit a story.

Accessibility 


\section{Are CEOs Born Leaders? Lessons from Traits of a Million Individuals}

Renée Adams

Matti Keloharju Samuli Knüpfer

Working Paper 16-044 


\section{Are CEOs Born Leaders? Lessons from Traits of a Million Individuals}

Renée Adams

University of New South Wales

Matti Keloharju

Harvard Business School

Samuli Knüpfer

BI Norwegian Business School

Working Paper 16-044 


\title{
Are CEOs Born Leaders? Lessons from Traits of a Million Individuals*
}

\author{
Renée Adams \\ University of New South Wales, ABFER, ECGI, and FIRN \\ Matti Keloharju \\ Aalto University School of Business, Harvard Business School, CEPR, and IFN \\ Samuli Knüpfer \\ BI Norwegian Business School, CEPR, and IFN
}

October 13,2015

\begin{abstract}
What makes a CEO? We merge data on the traits of more than one million Swedish males, measured at age 18 in a mandatory military enlistment test, with data on their service as a CEO of any Swedish company decades later. CEOs have higher cognitive and non-cognitive ability scores and are taller than typical members of the population. The difference in traits is larger when CEOs run bigger companies; it is smaller when they run family firms, in particular in the capacity of an heir or in a less competitive industry. Although the traits of CEOs compare favorably with the population, they are hardly exceptional: for example, the median large-company CEO belongs to the top- $17 \%$ of the population in cognitive ability, and to the top-5\% in the combination of cognitive, non-cognitive ability, and height. There are more than one hundred times as many men in managerial roles in the corporate sector who have better trait combinations than the median large-company CEO and who do not become a large-company CEO during our 7-year sample period. Being born with a favorable mix of traits may be necessary but is far from a sufficient condition for making it to the executive suite.
\end{abstract}

JEL-classification: G30, J24, J31

\footnotetext{
*E-mails: renee.adams@unsw.edu.au, matti.keloharju@aalto.fi, samuli.knupfer@bi.no. We are grateful to Joao Cocco, Francesca Cornelli, James Dow, Alex Edmans, Andrea Eisfeldt, Julian Franks, Michael Faulkender, Xavier Gabaix, Neal Galpin, Denis Gromb, Magnus Henrekson, Dirk Jenter, Ross Levine, Alberto Manconi, Felix Meschke, Daniel Metzger, Paul Oyer, Matti Sarvimäki, Henri Servaes, Luke Taylor, Marko Terviö, Joacim Tåg, David Yermack, and Luigi Zingales, and to seminar and conference participants at the Aalto University, Beijing University, Birkbeck College, Copenhagen Business School, Erasmus University Rotterdam, London Business School, Lund University, Maastricht University, Renmin University, Research Institute of Industrial Economics (IFN), Southwestern University of Finance and Economics, Tilburg University, Tsinghua University, University of Bergen, University of Edinburgh, University of Geneva, University of St. Gallen, the Adam Smith Workshop for Corporate Finance, the 2015 EFA Conference, and the 2015 WFA Conference for valuable comments and suggestions. We thank Antti Lehtinen, Ivan Baranov, Petri Hukkanen, and Lari Paunonen for superb research assistance, Deloitte Institute of Innovation and Entrepreneurship, Jan Wallander and Tom Hedelius Research Foundation, Marianne and Marcus Wallenberg Foundation, OP-Pohjola Foundation, SNS Centre for Business and Policy Studies, and Wihuri Foundation for financial support, and IFN for hospitality.
} 


\section{Introduction}

Life histories of military leaders such as Alexander the Great, Napoleon Bonaparte, or Gustavus Adolphus of Sweden suggest that they were able to achieve remarkable success already in their twenties or thirties (Grossman 2007). Similarly, businessmen such as Bill Gates, Mark Zuckerberg, and Michael Dell founded and ran highly successful companies before their thirties (Davidson and Bolmeijer 2009). The early success of these and many other individuals has led many to revisit Carlyle's (1841) "Great Man Theory of Leadership" and ask whether successful leaders are born to their roles_and which traits set them apart (e.g. Bertrand 2009; Kaplan, Klebonov, and Sorensen 2012; Koehn 2014). ${ }^{2}$ Knowledge of the traits of leaders, and business leaders in particular, can help in refining theories of Chief Executive Officer (CEO) behavior; it can help in understanding differences between founders and professional managers; and it can help in differentiating talent-based and rent-seeking theories of managerial pay. Yet to date there is little data on the traits CEOs are endowed with. We present such data in this paper.

To examine whether CEOs are "born", we need data on CEOs before they become CEOs. We use unique data from Sweden to examine the personal traits at age 18 of top business leaders, members of other skilled professions, and the population in the years 2004-2010. The data come from the Swedish military which examines the physical, cognitive, and non-cognitive characteristics of all conscripts to assess whether they are physically and mentally fit to serve in the military and suitable for training for leadership or specialist positions. Military service was mandatory in Sweden during our sample period, so the relevant test pool for our sample includes

\footnotetext{
${ }^{2}$ A Google search confirms the popularity of the idea that leaders are born to their roles. Using the search term "born leader" returns 544,000 hits.
} 
virtually all Swedish men. Our sample consists of data on 1.3 million men born between 1951-1978. Of these men, 26,000 served as CEOs of companies of varying sizes at some point in our sample.

To examine whether CEOs are "born", we need to benchmark CEOs against other individuals. In addition to comparing CEO traits to the population, we compare them to more than 6,000 lawyers, 9,000 medical doctors, and 40,000 engineers. We also examine the traits of those who may be truly born to their roles: CEOs in family firms.

We examine how talent is allocated to CEO positions by focusing on three personal traits: cognitive and non-cognitive ability and height. Although talent is a broader concept, these traits have a long history of being associated with labor market outcomes in representative samples of the population. For example, an extensive literature finds that cognitive and non-cognitive traits and height significantly predict earnings of rank-and-file employees. ${ }^{3}$ We expect the traits to be even more relevant for CEOs who have more complex and demanding job descriptions, ranging from creating and implementing the firm's strategy to leading and evaluating people.

Apart from their general nature, the timing of the measurement of the traits works to our advantage. The traits are measured before individuals have accumulated substantial leadership experience or professional or educational specialization, so they can be largely viewed as innate. Consistent with this argument, Beauchamp et al. (2011) find in the Swedish military data that

\footnotetext{
${ }^{3}$ A large literature on the role of education and labor market outcomes uses cognitive skills as the sole proxy for ability (e.g. Herrnstein and Murray, 1996 and Schmidt and Hunter, 1998). Others argue that non-cognitive skills are also important for predicting labor market outcomes (e.g. Heckman, 1995 and Heckman, Stixrud and Urzua, 2006). Yet another sizeable literature documents that height is related to labor market outcomes and leadership (e.g. Steckel, 1995, 2009; Persico, Postlewhite, and Silverman, 2004; Case and Paxson, 2008; and Lindqvist, 2012). Mayew, Parsons and Venkatachalam (2013) relates voice pitch to labor market outcomes for CEOs. Bolton, Brunnermeier, and Veldkamp (2010) offer a tentative economic analysis on the elements of effective leadership.
} 
$66 \%-93 \%$ of the variation in the traits we examine can be attributed to genetic and environmental factors shared by the male siblings of a family.

We find that CEOs display considerably higher trait values than the population as a whole. The traits of large-company CEOs (defined here as having at least SEK 10 billion or USD 1.2 billion in total assets) are about at par or higher than those of medical doctors, lawyers, and engineers. CEOs managing smaller firms and family firms have lower traits, particularly if they come from the founding family and have not founded the company themselves. Consistent with Pérez-González (2006), Bennedsen et al. (2007), and others, these results suggest that family firms appear to be making compromises in the traits of the CEO by limiting their selection of the CEO to a narrow pool of family candidates. Somewhat surprisingly, even founder CEOs, many of whom have an impressive track record in building up and growing the business, exhibit on average $0.1-0.2$ standard deviations lower traits than non-family company CEOs. As a manifestation of their business acumen, they make up for about half of this trait gap by selecting into industries where the gap relative to competitors is smaller.

All three traits are correlated with the likelihood a member of the population becomes a CEO. This is true even within educational major and the same family. Non-cognitive ability is the best predictor of an appointment to a CEO position, followed by cognitive ability and height. Cognitive ability is more important for larger companies that are more likely to hire their CEOs externally: the median large-firm CEO is in the top $17 \%$ of the population in cognitive ability.

While CEOs are smarter than average, they are not as smart as one could infer from the prior literature. Swedish CEOs do not belong to the "cognitive elite" comprising the top-5\% of individuals, as defined by Herrnstein and Murray (1996) in "The Bell Curve", not to mention the "higher professional" category of the top $0.1 \%$ of individuals of Burt (1924). In fact, the 
cognitive ability of Swedish large-firm CEOs is even lower than Herrnstein and Murray's (1996, p. 60) estimate of the cognitive ability of 12.9 million Americans working in executive, administrative, and managerial positions in the corporate sector. This category contains many more jobs at many more levels and in much smaller companies than the position of a large-firm CEO. ${ }^{4}$

The discrepancy between prior estimates of CEO IQ and our evidence suggests leadership ability cannot be boiled down to a single trait (see e.g. Heckman, 1995) or circumstance. ${ }^{5}$ Indeed, if we use a weighting scheme implied by the traits' impact on CEO appointments, the median large-company CEO makes a top 5\% "elite" cutoff in the combination of his traits. But there are still more than one hundred times as many men in managerial roles in the corporate sector who have better trait combinations than the median large-company CEO and who do not become a large-company CEO during our 7-year sample period. Being born with a favorable mix of the three traits may be necessary but is far from a sufficient condition for making it to the executive suite.

CEOs are paid very well, but not because of their traits: only about one tenth of the $1200 \%$ pay premium large-firm CEOs enjoy over the population can be attributed to the three traits. The other high-talent professions we study have much lower pay premiums, and the traits also do a better job explaining them. These results add to the evidence that the traits are not in scarce supply in the CEO labor market.

\footnotetext{
${ }^{4}$ Similarly, Wai (2013) estimates that $38.6 \%$ of the CEOs of Fortune 500 firms attended a school requiring standardized test scores "that likely places them in the top $1 \%$ of ability." We find that $17 \%$ of large-firm CEO belong to the top $4 \%$ (not the top $1 \%$, a much tougher screen) in cognitive ability. While Swedish large-firm CEOs are running companies that are on average smaller than the Fortune 500 firms, they are still the largest firms in the country.

${ }^{5}$ Herrnstein and Murray (1996) and Wai (2014) discuss the role of financial constraints and educational opportunities on occupational outcomes.
} 
Would the pattern in CEOs traits look different in other countries? We doubt it. Sweden has had many world-class companies since the late 19th century (Olsson 1993); on a per capita basis, there were above 50\% more Swedish companies in the 2013 Forbes Global 2000 list than US or UK corporations. Few large Swedish companies are government-owned (Faccio and Lang 2002), and the managing practices of mid-sized Swedish companies are among the best in the world (Bloom and van Reenen 2010). We expect Swedish CEOs to be selected at least as carefully as their peers in most other industrialized countries.

Our paper is related to four strands of literature. First, the paper is related to a wide array of recent economics and finance studies that analyze the effect of CEOs on various firm outcomes. ${ }^{6}$ Bertrand and Schoar (2003) and Graham, Li, and Qiu (2012) document that CEO-level fixed effects matter for corporate policies and firm performance. To find out what accounts for these fixed effects, researchers have looked into observable CEO characteristics, collected usually from bibliographic data ${ }^{7}$ or surveys. ${ }^{8}$ In some studies, CEO ability or characteristics are inferred from stock price reactions or operating performance ${ }^{9}$ or from personal portfolio decisions. ${ }^{10}$

\footnotetext{
${ }^{6}$ E.g. Bertrand and Schoar 2003; Adams, Almeida, and Ferreira 2005; Malmendier and Tate 2009; Chang, Dasgupta, and Hilary 2010; Schoar and Zuo 2011; Benmelech and Frydman 2015; Falato, Li, and Milbourn 2015; Graham, Li, and Qiu 2012; Custódio, Ferreira, and Matos 2013; Custódio and Metzger 2013; Graham, Harvey, and Puri 2013; Mullins and Schoar 2013; Bandiera et al. 2015. For a related management literature, see, for example, Lieberson and O'Conner 1972; Hambrick and Mason 1984; Thomas 1988; Finkelstein, Hambrick, and Cannella 2009; and Hiller et al. 2011. As pointed out by Bertrand and Schoar (2003), the focus of this literature and the methodological approach it follows differ substantially from that in the economics and finance papers.

7 Adams, Almeida, and Ferreira 2005; Malmendier and Tate 2009; Schoar and Zuo 2011; Benmelech and Frydman 2015; Falato, Li, and Milbourn 2015; Custódio, Ferreira, and Matos 2013; Custódio and Metzger 2013; and Graham, Harvey, and Puri 2013.

${ }^{8}$ Graham, Harvey, and Puri 2013; Mullins and Schoar 2013; and Bandiera et al. 2015.

9 Johnson et al. 1985; Pérez-González 2006; Bennedsen et al. 2007; Bennedsen, Pérez-González, and Wolfenzon 2010; Bennedsen, Pérez-González, and Wolfenzon 2012; and Chang, Dasgupta, and Hilary 2010.

${ }^{10}$ Malmendier and Tate 2005, 2008; Malmendier, Tate, and Yan 2011; and Hirshleifer, Low and Teoh 2013.
} 
Many of these studies focus on the CEOs of family companies and the differences between the founder and later generations. ${ }^{11}$ Our study differs from this literature in its focus on managerial inputs rather than on the outputs the firm generates. Managerial inputs can be observed with much less noise than outputs such as performance and they are not subject to the equilibrium forces that render the relations between outcomes and managerial inputs difficult to detect. $^{12}$

Second, our paper is related to a vast literature on CEO pay. ${ }^{13}$ One strand of this literature points to rising CEO pay in the US and argues it is the outcome of rent-seeking (e.g. Yermack 1997, Betrand and Mullainathan 2001, and Bebchuk and Fried 2004). CEO talent, other than perhaps the talent to steal, does not play an explicit role in this view. Another strand of the literature points to the same trend and argues it is the outcome of a matching process of rare CEO talent to firms of different sizes (e.g. Gabaix and Landier 2008, Terviö 2008, Edmans and Gabaix 2011, Eisfeldt and Kuhnen 2013, and Gabaix, Landier, and Sauvegnat 2014; Murphy, Shleifer, and Vishny 1991 study the allocation of talent in the economy and its implications for growth). The theory based on matching does not, however, take a stand on the nature of the executives' scarce talent. By analyzing general, and largely innate, traits, we show that executives' raw talent explains their matching into firms, although far from perfectly. The traits the labor market uses to rank CEO candidates thus do not appear to be confined solely to the early-life traits economists frequently use to predict labor market outcomes.

\footnotetext{
${ }^{11}$ Anderson and Reeb 2003; Pérez-González 2006; Bennedsen et al. 2007; and Bennedsen, Pérez-González, and Wolfenzon 2010, 2012.

${ }^{12}$ In equilibrium, there is no link between talent and performance. Gabaix and Landier (2008) analyze an out-ofequilibrium outcome in which a company hires at no extra salary cost a much more highly ranked executive than is justified by the company's own rank. This leads to only a small improvement in corporate performance.

${ }_{13}$ Murphy (1999), Frydman and Jenter (2010), Murphy (2012), and Edmans and Gabaix (2015) review this literature. Fernandes et al. (2013) report comparative evidence on CEO compensation in 14 countries.
} 
Third, our study is related to papers that analyze the characteristics or compensation of other well-paid professionals, including lawyers (Kaplan and Rauh 2010, 2013 and Oyer and Schaefer 2012), finance professionals (Kaplan and Rauh 2010, 2013; Philippon and Resheff 2012; and Célérier and Vallée 2014), and entrepreneurs (Levine and Rubinstein 2015). Perhaps the closest to ours are the studies by Lindqvist and Vestman (2011) and Lindqvist (2012), which match enlistment test data with the income of individuals in managerial positions. These individuals account for $8 \%$ of the male population and are thus on average considerably lower on the corporate ladder than CEOs. These studies also lack data on firm size, a key attribute in assignment models.

Fourth and finally, our paper is related to the labor and finance literature that studies the relationship between ownership structure and employment decisions. Bloom and Reenen (2007) study the link between ownership structure and various management practices, including those concerning monitoring and incentives. Olsson and Tåg (2015) investigate the employment effects of private equity firms. Sraer and Thesmar (2007) and Mueller and Philippon (2011) study family firms. Matsa and Miller (2014) study employment practices as a function of gender. Our paper differs from these papers both in its use of rich talent proxies and focus on CEOs. 


\section{Data}

Our data set combines information from the Military Archives, Statistics Sweden and the Swedish Companies Registration Office. ${ }^{14}$ We utilize a panel of trait data on men born between 1951-1978 whose occupations we can observe in the period 2004-2010.

Military Archives. The traits data originate from the Swedish military, which examines the health status and the cognitive, non-cognitive, and physical characteristics of all conscripts. The purpose of the data collection is to assess whether conscripts are physically and mentally fit to serve in the military and suitable for training for leadership or specialist positions. The examination spans two days and takes place at age 18. Lindqvist and Vestman (2011) offer a more comprehensive description of the testing procedure.

The data are available for Swedish males who were drafted between 1970 and 1996. Military service was mandatory in Sweden during this period, so the test pool includes virtually all Swedish men. The data record the year in which the conscript was enlisted.

The cognitive-ability test consists of four subtests designed to measure inductive reasoning (Instruction test), verbal comprehension (Synonym test), spatial ability (Metal folding test), and technical comprehension (Technical comprehension test). The subscores and their aggregation into a composite score are reported on a stanine (STAndard NINE) scale. On this scale a normal distribution is divided into nine intervals, each of which has a width of 0.5 standard deviations excluding the first and last. An individual's test score thus tells how well he performed relative to an entire cohort of test takers.

\footnotetext{
${ }^{14}$ The sensitive nature of the data necessitated an approval from the Ethical Review Board in Sweden and a data secrecy clearance from Statistics Sweden. The identifiers for individuals, firms, and other statistical units were replaced by anonymized identifiers and the key that links the anonymized identifier to the real identifiers was destroyed. The data are used through Microdata Online Access service provided by Statistics Sweden.
} 
Psychologists use test results and family characteristics in combination with one-on-one semi-structured interviews to assess conscripts' psychological fitness for the military. Psychologists evaluate each conscript's social maturity, intensity, psychological energy, and emotional stability and assign a final aptitude score following the stanine scale. Conscripts obtain a higher score in the interview when they demonstrate that they have the willingness to assume responsibility, are independent, have an outgoing character, demonstrate persistence and emotional stability, and display initiative. Importantly, a strong desire for doing military service is not considered a positive attribute for military aptitude (and may even lead to a negative assessment), which means that the aptitude score can be considered a more general measure of non-cognitive ability (Lindqvist and Vestman 2011).

To assess physical aptitude for military service, the military collects physical information about conscripts including their height. In robustness checks, we also use supplementary data from a variety of strength and fitness tests. Prior literature shows that physical fitness modifies the relationship between height and labor market outcomes (Lindqvist 2012; Lundborg, Nystedt, and Rooth 2014). Cardiovascular fitness is measured in a cycle ergometry test and muscle strength on a combination of knee extension, elbow flexion, and hand grip tests.

Statistics Sweden. We merge the traits data to personal characteristics obtained from Statistics Sweden. The bulk of these data comes from the LISA database that covers the whole Swedish population of individuals who are at least 16 years old and resident in Sweden at the end of each year. This database integrates information from registers held by various government authorities. We extract information on labor and total income, corporate ownership at the personfirm level, field and level of education, profession, and family relationships. Labor income includes all income taxed as labor income in a given year; base salaries, stock option grants, 
bonus payments, and benefits qualify as taxable labor income. ${ }^{15}$ The education levels consist of five categories that vary from basic education to graduate studies. We use the fields of education to classify degrees into law, business, administration, government, natural sciences, agriculture, engineering, medicine, and other fields. Occupation codes, based on the international ISCO-88 classification, define physicians (referred to in the text as medical doctors), lawyers, engineers, and other occupations. The family records allow us to map each individual to their parents and siblings.

Swedish Companies Registration Office. The Swedish Companies Registration Office keeps track of all companies and their top executives and directors. The firm data are available for all corporate entities that have a limited liability structure ("aktiebolag") and that have appointed a CEO ("verkställande direktör"), excluding firms that operate as banks or insurance companies. These data record various financial statement items, including the total value of assets and the number of employees. By law, each firm has to supply this information to the registration office within seven months from the end of the fiscal year. Financial penalties and the threat of forced liquidation discourage late filing. The 40 industries in our data are based on the international NACE Rev.1.1 classification. The information on service as CEO tells us, at the end of each year, the identification number of each firm and the individual who serves as its CEO.

We classify companies as family firms on the basis of family relations among major shareholders, called "owners" by the tax authorities, and directors. An individual's family comprises his parents, grandparents, children, grandchildren, siblings, and partner(s). A partner is the person with whom the individual has a child.

\footnotetext{
15 Tax authorities deem the taxable income to occur in the year when an employee or executive exercises his stock options or purchases his company's shares at a price that is less than their fair value.
} 
For each owner and director in a firm, we calculate the number of other family members who are directors or owners in the company. A company is a family firm if at least two family members are owners or board members or at least one owner and one director comes from the same family.

A family-managed company is a family firm whose CEO is related to at least one director or owner of the company. We classify a family-managed firm as heir managed if the CEO was between the age of 0 and 18 at the time the firm was founded, he is at least 20 years younger than the oldest family member who is a director or owner, or he is at least 20 years younger than the family member who previously served as the CEO of the company. We assign all family firms that are not managed by the later generation to the founder category.

The data we use to characterize family ownership originate from the tax filings in which individuals declare ownership in limited liability firms. Importantly, individuals must also declare ownership of a firm through another holding company in the tax form. This allows us to track ultimate owners of a company. Following Bennedsen et al. (2012), we exclude micro firms from the sample, defined here as having fewer than five employees or an asset base below SEK 1 Million ( $1 \mathrm{SEK} \approx 0.12 \mathrm{USD}$ ). The former restriction also helps in excluding holding companies without their own industrial operations from the sample.

Our sample includes about 26,000 unique CEOs. We assign CEOs to firm-size categories based on the size of the largest firm they manage during the period 2004-10. Small companiesthose with less than SEK 100 million (USD 12 million) in total assets-account for 84\% of the firm population. Small-to-medium size companies are those with assets between SEK 100 million and 1 billion. Medium-to-large companies have assets between SEK 1 billion and 10 billion and large companies have more than SEK 10 billion in assets (USD 1.2 billion). 
Our entire sample encompasses about 9 million person-years. Given the sample size, almost all of our results are highly significant. Therefore, our reporting generally focuses on coefficient values and patterns rather than on their statistical significance.

\section{Ranking CEOs by Their Individual Traits}

This section compares the traits of CEOs to those of other high-skilled professionals and members of the population. We first analyze how much weight the CEO labor market gives to each trait and the cognitive ability subcomponents. We then examine whether firm size and family ownership and management moderate the importance of traits. In particular, we ask whether the CEO labor market allocates CEOs with higher trait values to more productive positions in larger companies, and whether the relationship between traits and firm size is weaker for family-managed firms that may choose CEOs from a smaller talent pool.

\subsection{Comparing CEOs to Other Skilled Professionals and Members of the Population}

In Panel A of Table 1, we report descriptive statistics of the traits, education, and income for

the population and three high-skill professions. The average member of the population has a cognitive ability score of 5.2, a non-cognitive ability score of 5.1, and is $179.1 \mathrm{~cm}$ tall. Medical doctors, engineers, and lawyers score better in all traits. The average cognitive ability scores of these professions are 7.5, 7.1, and 6.7, respectively, denoting a difference of $0.8-1.2$ standard deviations relative to the population. The corresponding difference in non-cognitive ability ranges from 0.5 to 0.7 standard deviations, and in height from 0.2 to 0.3 standard deviations.

- Insert Table 1 about here-

Panel B of Table 1 reports descriptive statistics for the traits, education, and income of CEOs of firms of different sizes. Future CEOs differ from the population in all measures we 
consider. The CEOs of small companies have a cognitive ability score of 6.0, a non-cognitive ability score of 6.1 , and are $180.3 \mathrm{~cm}$ tall. Thus, small-company CEOs have about one-half of a standard deviation higher cognitive and non-cognitive ability, and are about one-fifth of a standard deviation taller than the population average, placing them at about par with engineers and lawyers in all traits except for cognitive ability. CEOs are also better educated than the population in general. Almost half the small-company CEOs have a college degree; the corresponding fraction for the population is about one-third.

On average CEO traits are better in larger firms. When we move from small to large companies, CEOs' average cognitive ability increases about two-thirds of a standard deviation: from 6.0 to 7.2. The corresponding increase for non-cognitive ability is from 6.1 to 7.4 and for height from $180.3 \mathrm{~cm}$ to $183.5 \mathrm{~cm}$. All traits of large-company CEOs are at about par or higher than those of medical doctors, lawyers, and engineers. CEOs of large firms are also better educated, older, and better paid than CEOs of smaller firms. In large firms, CEOs receive on average SEK 6 million; in small firms, they receive SEK 752 thousand.

Carlstedt and Mårdberg (1993) argue that that induction and verbal reasoning are more highly associated with the "general factor" in intelligence, the g-factor, than the other subcomponents of cognitive ability. Among CEOs, these factors increase the most as a function of firm size. For example, the average induction score increases from 6.0 to 7.1 from small to large companies, while the average technical ability only increases from 5.6 to 6.1 . These results are consistent with Murphy and Zábojník (2004, 2007) and Frydman (2007)'s arguments that general managerial skills (i.e., skills transferable across companies, or even industries) are important in the CEO labor market.

-Insert Figure 1 about here- 
Panels A and B of Table IA1 in the appendix report the distribution of the traits across stanines in the population, high-skilled professions, and among CEOs of companies of varying sizes. Panel A of Figure 1 graphs the distribution of the traits, both for the population and for CEOs of small and large companies. The figure illustrates that the difference in the average scores between the population and CEOs does not arise from a preponderance of any one stanine in any of the groups. There are relatively fewer CEO participants in every below-average trait group and relatively more in every above-average trait group.

\subsection{Traits in Family and Non-Family Firms}

Since within-family succession is one mechanism families use to maintain control, it is plausible that CEO traits in family firms are different from those in non-family firms. We divide our sample into non-family owned firms (64\% of our sample firms) and family-owned firms. Family-owned companies are either managed by the founder (25\% of the sample), an heir $(6 \%)$, or an external CEO (6\%).

Panel A of Table 2 shows descriptive statistics for CEOs by family firm status; Panels A and C of Table IA1 break down the distribution of the traits by family firm status. Non-family company CEOs have slightly higher cognitive ability (6.3) than external CEOs in family firms (6.2) and about one-third of a standard deviation higher cognitive ability than founder- or heirmanaged family firms. Non-cognitive ability and height follow the same ranking between firm types. Panel B of Figure 1 illustrates the difference between family and non-family companies by graphing the distribution of the three key traits in the population and for CEOs of family and non-family companies.

The univariate results suggest that family firms, especially those with family management, employ CEOs with lower trait values. However, these firms also tend to be the smaller. For 
example, average assets in non-family companies are SEK 600 million, while average assets in founder-managed (heir-managed) companies are SEK 38 million (71 million), respectively. To disentangle the effects of family ownership from the effect of firm size, we regress CEO traits on firm size and ownership type in the sample of CEOs.

- Insert Table 2 about here-

Panel B of Table 2 shows regressions of each CEO trait on indicators for externally managed, founder-managed, and heir-managed family companies and on logged total assets. The omitted category is the non-family firm category. For each trait there are two specifications: one excluding industry fixed effects (columns marked with odd numbers), and one including them (columns marked with even numbers). To control for possible time variation in the quality of CEOs and an upward trend in mean cognitive ability scores and height in the population (Flynn 1984, Floud, Wachter, and Gregory 1990), we add controls for year and enlistment year in all specifications.

In all columns, the coefficients on the family ownership dummies are negative. From column 1 , we see that externally managed family-firm CEOs have 0.08 standard deviations lower cognitive ability than non-family firms. The corresponding numbers for founder- and heirmanaged family firms are 0.23 and 0.27 standard deviations, respectively. The rankings of coefficients are similar for non-cognitive ability (column 3) and height (column 5). As a general rule, heir-managed family-company CEOs have the lowest and founder-CEOs the second-lowest trait values. The difference between these two categories is greatest for non-cognitive ability, where heirs have on average 0.11 standard deviations lower trait values than founders. These results are consistent with the evidence of Pérez-González (2006) and Bennedsen et al. (2007), 
who find that family appointments due to a generation change tend to lead to lower firm performance.

Columns 2, 4, and 6 add industry fixed effects to the regressions. This reduces the size of all coefficients on the family ownership indicators. Each coefficient in the cognitive ability specification in column 2 decreases by at least $46 \%$, while the corresponding drops for noncognitive ability and height in columns 4 and 6 are at least $30 \%$. These results are consistent with the idea that family firms are more likely to survive in industries in which they face a smaller talent disadvantage relative to their competitors.

The assignment models of Gabaix and Landier (2008), Terviö (2008), and others predict that more talented CEOs are allocated to bigger firms. Consistent with their predictions, we find that the coefficients on logged total assets are all positive in Table 2. Thus, the relationship between firm size and CEO talent is robust to controlling for family firm status. But assignment models are silent on the role of ownership structure. Because non-family firms choose their CEOs from a bigger pool, it is plausible that both the firm size - talent relationship and the firm size - pay relationship are stronger in non-family firms. To examine this hypothesis, we first provide some visual evidence on the role of assignment in the full sample and then examine the relationship between traits, firm size, and pay in ownership subsamples.

- Insert Figure 2 about here-

We sort CEOs into 250 quantiles based on firm size. In Panel A of Figure 2, we plot for each quantile the mean standardized traits (vertical axis) against logged average total assets (horizontal axis). In Panel B, we plot logged mean CEO pay against logged average total assets; In Panel $\mathrm{C}$ we plot mean standardized traits (vertical axis) against logged mean CEO pay. 
The plots in Figure 2 are consistent with assignment models. The relationship between traits and pay is monotonic and close to linear, suggesting that more talented CEOs are allocated to larger firms. There is also a monotonic and close to linear relationship between firm size and CEO pay. The size elasticity of pay, 0.27 , is quite close to the 0.3 estimate reported for U.S. firms (see, e.g., Murphy 1999). Finally, the traits have a monotonic and close to linear relationship with logged pay.

- Insert Table 3 about here

In Table 3, we revisit the relationship between firm size and talent after taking ownership structure into account. We regress firm size on traits and controls in the four ownership/management groupings. The correlations uncovered by these regressions are based on observed equilibrium outcomes and thus do not directly lend themselves to a causal interpretation. But examining the coefficients and adjusted $R$-squareds may still be informative about the extent to which our talent measures associate with firm size, both individually and collectively, in different types of companies. We expect the $R$-squareds to be lower in familymanaged companies, where the private benefits associated with employing a family member generate friction in the talent allocation process.

In our baseline specification we regress firm size on traits and controls for year and enlistment year. We then sequentially add industry fixed effects and education level and field fixed effects. Comparing across columns, we observe that the relationship between firm size and traits, particularly cognitive and non-cognitive ability, is strongest for non-family firms and weakest for heir-managed family firms. For example, a one standard deviation change in noncognitive ability is associated with a $22.3 \%$ (column 3 ) increase in logged assets in non-family firms, but only a $4.1 \%$ (column 6), $6.4 \%$ (column 9) and $4.2 \%$ (column 12) increase in logged 
assets in externally-managed, founder-run, and heir-managed family firms, respectively. Likewise, the R-squareds are highest for the non-family firms (e.g. 0.09 in column 1) and lowest for the founder- and heir-managed firms (e.g. 0.021 and 0.031 in columns 7 and 10).

These results suggest two things. First, the vast majority of the variation in the traits we use in our paper is not related to firm size. While we do not know what traits the labor market uses to rank CEO candidates, we can at least say that they do not appear to be confined to the narrow set of early-life traits economists frequently use to predict labor market outcomes. Second, the traits associate much less with firm size in family-managed firms than in other firms. This result is consistent with the idea that the CEO labor market works less well among family-managed companies, where the private benefits associated with hiring a family member or working in the family company may trump the goal of achieving the best possible CEO-firm match.

\section{Ranking CEOs by Their Trait Combinations}

Our evidence suggests that high individual trait values have explanatory power for the assignment to CEO positions within the population and across firms. In this section, we analyze the combinations of CEO traits and ask how unique their combined traits are when compared with the population and with other men pursuing managerial careers in the corporate sector.

\subsection{Ranking CEO Traits}

We analyze how the traits an individual possesses map into the likelihood of attaining a CEO position later in life. In Panel A of Table 4, we show the results of linear probability models that relate the CEO dummy to the three traits and fixed effects for the year of the data, the individual's enlistment year, and his education level and field. Column 6 includes family fixed 
effects which control for unobserved characteristics shared by brothers. Columns 1-3 consider each trait separately; columns 4-6 combine them.

Insert Table 4 about here-

All three traits are significantly positively associated with the likelihood an individual attains a CEO position. When analyzed alone, the coefficient for non-cognitive ability is 0.72 , whereas the corresponding coefficients for cognitive ability and height are 0.55 and 0.24 , respectively. Adding all trait variables simultaneously to the regression in column 4 decreases their individual coefficients, but their relative importance remains: with a coefficient of 0.59 , non-cognitive ability has most predictive power for CEO appointments, followed by cognitive ability (a coefficient of 0.31 ), and height (a coefficient of 0.12 ). The ranking in traits persists even after controlling for educational attainment and family fixed effects.

To get a better sense of what the numbers mean, one can do the following thought experiment. Following the convention that one standard deviation in cognitive ability corresponds to 15 IQ points, and using the Table 1 result that the population standard deviation in height is 6.54 centimeters, these results imply that in CEO selection each centimeter in height corresponds to $(0.12 \times 15) /(6.54 \times 0.31)=0.91$ IQ points.

Panel B of Table 4 analyzes how the subcomponents of cognitive ability are associated with CEO appointments. Columns 1-4 report the results using only one component at a time. Induction, which captures logical ability and numeracy, has the largest coefficient, followed by verbal ability, technical ability, and spatial ability. This ranking remains the same when we combine the subcomponents in columns 5-7 and control for the level and field of education (column 6) and family fixed effects (column 7). 
Since the traits attain discrete values, we smooth them by interpolating between one-percent intervals of the CEO distribution. For example, Panel B of Table 1 shows that the median CEO of a firm with more than 10 billion in assets has a cognitive-ability score of 7. Panel B of Table IA1 shows that the cognitive ability of this CEO falls between the sixth and seventh stanines and that the cumulative shares of CEOs representing stanines $1-6$ and $1-7$ are $31 \%$ and $62 \%$, respectively. The corresponding population shares are $75 \%$ and $88 \%$, respectively. Therefore, the cumulative share of the population increases by $(88 \%-75 \%) /(62 \%-31 \%)=0.42$ for each one percent increase in the CEO population. Because the median is $50 \%-31 \%=19 \%$ away from the lowest point of the sixth stanine, the median CEO dominates $75 \%+0.42 \times 19 \%=83 \%$ of the population.

Panel A of Table 5 tabulates the proportion of the population that is dominated by smalland large-company CEOs in individual traits. The median small-company CEO is above $66 \%$ of the population in cognitive ability, above $73 \%$ in non-cognitive ability, and above $57 \%$ in height. The corresponding fractions of the population dominated by large-company CEOs are $83 \%$, $92 \%$, and $74 \%$, respectively. While CEOs have considerably higher trait values than the population as a whole, a substantial fraction of the population is not dominated by CEOs in traits. For example, $17 \%$ of the population have a higher cognitive ability than the median large-firm CEO.

Insert Table 5 about here-

While CEOs are smarter than average, they are not as smart as one could infer from the prior literature. Swedish CEOs do not belong to the "cognitive elite" comprising the top-5\% of individuals, as defined by Herrnstein and Murray (1996) in "The Bell Curve", not to mention the "higher professional" category of the top $0.1 \%$ of individuals of Burt (1924). In fact, the 
cognitive ability of Swedish large-firm CEOs is even lower than Herrnstein and Murray's (1996) estimate of the cognitive ability of 12.9 million Americans working in executive, administrative, and managerial positions in the corporate sector. ${ }^{16}$ This category contains many more jobs at many more levels and in much smaller companies than the position of a large-firm CEO.

It is possible that looking at CEOs one trait at a time is too narrow of an approach. Many argue that leadership ability is not one-dimensional (e.g. Heckman, 1995). And the fact that CEOs score well on all traits we consider suggests that CEOs may be exceptional in the combination of their traits. Since the predicted probabilities of attaining a CEO position in Table 4 are linear combinations of standardized traits, it is natural to use predicted probabilities as measures of combined traits to rank CEOs relative to the population (see e.g. Rosenthal 1978).

The coefficients in column 4 of Panel A, Table 4 suggest relative weights of $58 \%$ for noncognitive ability, $31 \%$ for cognitive ability and $12 \%$ for height in a combined trait. Using these weights, we tabulate the proportion of the population dominated by CEOs of firms of various sizes and ownership structures in Panel B of Table 5. Figure 3 provides graphical representations of the data for small and large firms; Figure 4 shows a more detailed visual comparison of the distributions of the combined trait by firm size and ownership type.

\section{- Insert Figure 3 about here}

Consistent with the idea that leadership ability is multi-faceted, CEOs differ more from the population in the combination of traits than in any individual trait. This result can be most easily seen in Figure 3, where the plot of the combined trait is always above the plots of each individual trait. However, the difference between the combined and the best individual trait is relatively

\footnotetext{
${ }^{16}$ On p. 60 , Herrnstein and Murray estimate that $70-80 \%$ of the Americans occupying these positions have an IQ of 120 , i.e. belong to the top $18 \%$ of the population in cognitive ability. The median Swedish large-firm CEO belongs to the top $17 \%$ of the population in cognitive ability.
} 
small, except for the bottom third of the CEOs of the largest companies. The median (top quartile) small-company CEO dominates $77 \%$ (91\%) of the population in the combined trait. The median (top quartile) large-company CEO dominates 95\% (99\%) of the population in the combined trait. This means that about $5 \%$ of the population, or more than 60,000 individuals, have a better trait combination than the median large-firm CEO. In Table IA2 we consider alternative weightings of the traits and show that this conclusion is robust to different weighting schemes.

-Insert Figure 4 about here-_

The left-hand plot of Panel A in Figure 4 illustrates how the proportion of the population dominated by CEOs changes as a function of the size of the firms they manage. There is a large difference in combined traits of small-company CEOs and those of firms whose total assets range from SEK 100 million to 1 billion. The trait difference between CEOs in other firm-size categories is smaller, particularly among the higher-ability CEOs. The right-hand plot of Panel A in Figure 4 depicts how the proportion of the population dominated by CEOs varies as a function of family ownership and management. The biggest difference in combined traits is between companies that are family managed, and those that are not. For example, the median family CEO dominates $68-73 \%$ of the population, while the median non-family CEO dominates $78-82 \%$ of the population in the combined trait.

\subsection{What Do the People with CEO-Caliber Traits Do?}

All talented individuals do not want to become CEOs. For example, some talented individuals choose an academic or medical career without any intention of pursuing a career as a corporate executive. To gain a better idea of the career intentions of talented individuals, we 
study the occupational outcomes of all test takers with at least as good of a combination of traits as the median CEO in various firm-size categories. This analysis allows us not only to exclude from our investigation of prospective CEOs those talented individuals who are unlikely to have considered a career as an executive, but also allows us to identify those individuals who have chosen to pursue a similar career, but with less success.

Panel C of Table 5 reports the career outcomes of these talented individuals. We divide their occupations into low-, medium- and high-skill categories as per Statistics Sweden. For the highskill group, we report specific occupational categories. Not surprisingly, most talented individuals work in high-skill professions such as management, IT, or engineering. While some talented individuals enter into academia (the Teaching category) or become doctors (Medicine), many of them pursue management careers that theoretically should culminate in a CEO position. Thirty-three percent of test takers (18,000 individuals) with combined traits dominating those of the median large-firm CEO belong to this category. Of these individuals, 3,610 are CEOs of smaller companies. Thus, there are more than 100 times as many high-talent individuals pursuing a lower-level managerial career and about 25 times as many high-talent smaller-firm CEOs as there are large-firm CEOs. Thus it appears as if preferences alone cannot explain why some talented individuals do not become CEOs.

\section{Traits and Pay}

The traits of CEOs are better than those of the population and of other high-skill professionals. But do these differences in traits help explaining why CEOs are paid so much? The fact that many individuals, including those in managerial positions in the corporate sector, have better traits than CEOs, suggests that the answer to this question is not obvious. We analyze 
the ability of traits to account for CEO pay by first establishing the position of the CEOs in the income distribution of the population. We then estimate the CEO pay premium and examine whether it can be attributed to CEOs' traits. To put our analysis in perspective, we compare the strength of CEOs' trait-pay relationship with that of medical doctors, engineers, and lawyers.

\subsection{Position of CEOs in the Income Distribution}

Panel D of Table 5 reports the proportion of the population that is dominated by CEOs in taxable labor income. The median small-firm CEO dominates $87 \%$ of the population in income. The median CEO in the 100 million to 1 billion size category dominates $98.8 \%$ of the population and the median large-firm CEO dominates $99.9 \%$ of the population in income. In other words, only $0.1 \%$ of the population earns more than the median large-firm CEO even though $5 \%$ of the population has a better combination of traits than this CEO. CEOs appear to differ from the population more in their pay than in their traits. Comparing the left-hand side plots in Panels A and B of Figure 4 provides visual confirmation of this result.

The four rightmost columns in Panel D of Table 5 show the extent to which CEO income in firms with different ownership types dominates population income. Non-family company CEOs are paid the most; the median non-family company CEO dominates $94 \%$ of the population in pay. Founders dominate only $79 \%$ of the population in pay, presumably because they tend to head smaller companies. The pay of heirs and professional family-company CEOs fall in between these two extremes. The right-hand side of Panel B Figure 4 illustrates these results graphically. 


\subsection{How the CEO Pay Premium Varies with Traits}

In Table 6, we examine the role of traits in CEO pay. The dependent variable is the logged taxable labor income an individual receives in a given year. Individuals with no taxable labor income are not included in the regression.

We first compare CEO pay to income in other high-skill professions and the population. This analysis yields estimates of the pay premiums of CEOs and of other high-skill professions. Then we add the traits and other controls to the regressions. The regression that includes traits tells us how much of a profession's pay premium over the population cannot be attributed to the traits of the typical member of the profession. The regression obtains this number by making a prediction of the pay premium based on the profession's traits and then subtracting this prediction from the true observed pay premium.

Column 1 reports results from a specification that includes dummies for CEOs of varioussized companies, dummies for medical doctors, lawyers, and engineers, and controls for year and enlistment year. The coefficient estimates for CEOs increase monotonically with firm size, ranging from 0.60 for the small-firm CEOs to 2.52 for large-firm CEOs. This means that smallfirm CEOs earn about 1.8 times as much as the population $\left(e^{0.60}=1.8\right)$ and large-firm CEOs about 12 times as much as the population. Medical doctors earn 2.3 times, lawyers 1.9 times, and engineers 1.7 times as much as the population.

- Insert Table 6 about here-

Column 2 adds controls for the three traits. The coefficient for large-firm CEOs drops from 2.52 to 2.26 , suggesting that only $10.3 \%$ of the large-firm CEO pay can be attributed to the three traits. Large-firm CEOs earn 9.6 times as much as the population after controlling for traits, while the equivalent premiums for the other high-skill professions are much smaller, ranging 
from 1.4 (engineers) to 1.9 (medical doctors). It appears that CEOs' traits are not even close to being sufficiently high to match the levels of their pay.

Columns 3-4 control for education and family fixed effects. The medical doctor, lawyer, and engineer dummies drop out of these regressions because we control for the field of education. In Column 4 the coefficients for CEOs, particularly for large-company CEOs, drop markedly: large-company CEOs make 2.7 times as much as their equally well educated brothers. Despite of the drop, the pay premium for CEOs remains higher than what it is for the other highincome professions in the other specifications. Our results are qualitatively similar if we use total income in lieu of ordinary income (Table IA3) or if we replace cognitive ability with its subcomponents (Table IA4).

These results suggest that the high pay CEOs enjoy does not arise from scarce supply of the three traits we study. While a favorable mix of traits may make it easier to climb on the corporate ladder, it by no means assures a position as a chief executive of a major company.

\section{Conclusion}

Perhaps the oldest theory of leadership, going back to Carlyle (1841), maintains that leaders are born to their roles. We test this theory by studying the traits of a comprehensive sample of future Swedish top business leaders at age 18 and by comparing them to the male population. Although we find that the traits of CEOs compare favorably with the population, they are hardly exceptional: for example, the median large-company CEO belongs to the top- $17 \%$ of the population in cognitive ability, and to the top-5\% in the combination of cognitive, non-cognitive ability, and height. All in all, more than 60,000 men in our sample have a similar or better trait combination than the median large-firm CEO. The traits CEOs are born with also leave the CEO 
pay premium largely unexplained. To the extent that the traits we use capture the traits that count in CEO selection, our results speak against the idea that top business leaders are selected primarily based on the traits they are born with.

What prevents individuals born with impressive portfolios of traits to enter top business positions? One possibility relates to the supply of talent: the non-pecuniary aspects of the executive job may make it unappealing to some talented individuals. We test this conjecture by studying all men who display a similar or better combination of the three traits than the median large-firm CEO and who work in managerial roles in the corporate sector. There are more than one hundred times as many high-talent men in lower-level managerial careers and about 25 times as many high-talent smaller-firm CEOs as there are large-firm CEOs. While pressure, uncertainty, and the public nature of an executive job can certainly render it unattractive, such preferences would need to apply to a very large share of these individuals to keep them away from pursuing a career as a professional executive. Although preferences are notoriously difficult to measure, these considerations make us skeptical about their ability to explain the lack of supply of CEO talent.

It is also possible that the CEO labor market emphasizes other intrinsic traits than the ones we study. We focus on three early-life traits economists frequently use to predict labor market outcomes, and that the Swedish military itself uses for officer selection. But we can also check whether future CEOs excel in other, less obvious ways. CEOs often have to endure long working hours and may need an excellent physical condition to meet the challenges in their work, so we test whether two physical-condition proxies, cardiovascular fitness and muscle strength at age 
18, have predictive power for attaining a CEO position. ${ }^{17}$ Table IA5 shows that physical condition is of little consequence once we control for the other traits, perhaps because physical condition can change substantially between the military service and the appointment to a CEO position. Although we cannot rule out the importance of traits we cannot observe, it is unclear what other traits individuals may be born with would be more relevant for becoming a CEO.

Our results raise the possibility that imperfections in the CEO labor market, such as onthe-job revelation of talent, may induce firms to demand experienced individuals at the expense of new talent (Terviö 2009). A proven track record in the early stages of an individual's career may outweigh the intrinsic talent of an inexperienced candidate. Personal traits may still play a role in such a market if it is easier for talented individuals to gain valuable experience. However, the relationship between traits and experience is bound to be noisy: candidates for early-career positions may be screened less intensively, and some applicants may find a job through sheer luck. Given that moderately talented individuals outnumber highly talented individuals, this noise means that the most talented individuals may not gain the best work experience. Although the role of experience remains challenging to identify, we see much hope in future analyses of the interplay between personal traits and work experience for explaining the allocation of talent.

\footnotetext{
${ }^{17}$ Lindqvist (2012) and Lundborg, Nystedt, and Rooth (2014) find these variables to predict life outcomes.
} 


\section{References}

Adams, Renée, Heitor Almeida and Daniel Ferreira, 2005, Powerful CEOs and Their Impact on Corporate Performance, Review of Financial Studies 18(4), 1403-1432.

Anderson, Ronald and David Reeb, 2003, Founding-Family Ownership and Firm Performance: Evidence from the S\&P 500, Journal of Finance 58(3), 1301-1327.

Bandiera, Oriana, Luigi Guiso, Andrea Prat, and Raffaella Sadun, 2015, Matching Firms, Managers, and Incentives, Journal of Labor Economics 33(3), 623-681.

Beauchamp, Jonathan, David Cesarini, Magnus Johannesson, Erik Lindqvist, and Coren Apicella, 2011, On the Sources of the Height-Intelligence Correlation: New Insights from a Bivariate ACE Model with Assortative Mating, Behavior Genetics, 41(2), 242-252.

Bebchuk, Lucian and Jesse Fried, 2004, Pay without Performance: The Unfulfilled Promise of Executive Compensation, Harvard University Press, Cambridge.

Benmelech, Efraim and Carola Frydman, 2015, Military CEOs, Journal of Financial Economics $117(1), 43-59$.

Bennedsen, Morten, Francisco Pérez-González, and Daniel Wolfenzon, 2010, Do CEOs Matter? Stanford University working paper.

Bennedsen, Morten, Francisco Pérez-González, and Daniel Wolfenzon, 2012, Evaluating the Impact of The Boss: Evidence from CEO Hospitalization Events, Stanford University working paper.

Bennedsen, Morten, Kasper M. Nielsen, Francisco Pérez-González, and Daniel Wolfenzon, 2007, Inside the Family Firm: The Role of Families in Succession Decisions and Performance, Quarterly Journal of Economics 122(2), 647-691.

Bertrand, Marianne, 2009, CEOs, Annual Review of Economics, 1(1), 121-150

Bertrand, Marianne, and Sendhil Mullainathan, 2001, Are CEOs Rewarded for Luck? The Ones without Principals Are, Quarterly Journal of Economics 116(3), 901-932.

Bertrand, Marianne and Antoinette Schoar, 2003, Managing with Style: The Effect of Managers on Firm Policies, Quarterly Journal of Economics 118(4), 1169-1208. 
Bloom, Nicholas, and John Van Reenen, 2007, Measuring and Explaining Management Practices across Firms and Countries, Quarterly Journal of Economics 122(4), 1351-1408.

Bloom, Nicholas, and John Van Reenen, 2010, Why Do Management Practices Differ across Firms and Countries? Journal of Economic Perspectives 24(1), 203-224.

Burt, Cyril, 1924, The Principles of Vocational Guidance (II), British Journal of Psychology General Section 14(4), 336-352.

Carlstedt, Berit, and Bertil Mårdberg, 1993, Construct Validity of the Swedish Enlistment Battery, Scandinavian Journal of Psychology 34(4), 353-362.

Carlyle, Thomas, 1841, On Heroes, Hero-Worship, and the Heroic in History, James Fraser, London.

Case, Anne and Christina Paxson, 2008, Height, Ability, and Labor Market Outcomes, Journal of Political Economy 116(3), 499-532.

Chang, Yuk Ying, Sudipto Dasgupta, and Gilles Hilary, 2010, CEO Ability, Pay, and Firm Performance, Management Science 56(10), 1633-1652.

Célérier, Claire and Boris Vallée, 2014, Are Bankers Worth Their Pay? Evidence from a Talent Measure, HEC working paper.

Custódio, Cláudia, Miguel Ferreira, and Pedro Matos, 2013, Generalists versus Specialists: Lifetime Work Experience and Chief Executive Officer Pay, Journal of Financial Economics 108(2), 471-492.

Custodio, Claudia, and Daniel Metzger, 2013, How Do CEOs Matter? The Effect of Industry Expertise on Acquirer Returns, Review of Financial Studies 26(8), 2008-2047.

Bolmeijer, Marjan, and Andrew Davidson, 2009, 1000 CEOs, Dorling Kindersley.

Edmans, Alex, and Xavier Gabaix, 2015, Executive Compensation: A Modern Primer, New York University working paper.

Edmands, Alex and Xavier Gabaix, 2011, The Effect of Risk on the CEO Market, Review of Financial Studies 24(8), 2822-2863. 
Eisfeldt, Andrea and Camelia Kuhnen, 2013, CEO Turnover in a Competitive Assignment Framework, Journal of Financial Economics 109(2), 351-372.

Faccio, Mara, and Larry HP Lang, 2002, The Ultimate Ownership of Western European Corporations, Journal of Financial Economics 65(3), 365-395.

Falato, Antonio, Dan Li, and Todd Milbourn, 2015, Which Skills Matter in the Market for CEOs? Evidence from Pay for CEO Credentials, Management Science, forthcoming.

Fernandes, Nuno, Miguel A. Ferreira, Pedro P. Matos, and Kevin J. Murphy, 2013, Are US CEOs Paid More? New International Evidence, Review of Financial Studies 26(2), 323-367.

Finkelstein, Sydney, Donald C. Hambrick, and Albert A. Cannella, 2009, Strategic Leadership: Theory and Research on Executives, Top Management Teams, and Boards (Oxford University Press, UK).

Floud, Roderick, Kenneth Wachter, and Annabel Gregory, 1990, Height, Health and History: Nutritional Status in the United Kingdom, 1750-1980 (Cambridge University Press, UK).

Flynn, James R., 1984, The Mean IQ of Americans: Massive Gains 1932 to 1978, Psychological Bulletin 95(1), 29-51.

Forbes, The World's Biggest Public Companies 2013, http://www.forbes.com/global2000/.

Frydman Carola, 2007, Rising Through the Ranks. The Evolution of the Market for Corporate Executives, 1936-2003, MIT working paper.

Frydman, Carola and Dirk Jenter, 2010, CEO Compensation, Annual Review of Financial Economics 2(1), 75-102.

Gabaix, Xavier, and Augustin Landier, 2008, Why Has CEO Pay Increased So Much? Quarterly Journal of Economics 123(1), 49-100.

Gabaix, Xavier, Augustin Landier, and Julien Sauvagnat, 2014, CEO Pay and Firm Size: An Update after the Crisis, Economic Journal 124(574), F40-F59.

Graham, John R., Campbell Harvey, and Manju Puri, 2013, Managerial Attitudes and Corporate Actions, Journal of Financial Economics 109(1), 103-121. 
Graham, John R., Si Li and Jiaping Qiu, 2012, Managerial Attributes and Executive Compensation, Review of Financial Studies 25(1), 144-186.

Grossman, Mark, 2007, World Military Leaders: A Biographical Dictionary, Infobase Publishing.

Hambrick, Donald C., and Phyllis A. Mason, 1984, Upper Echelons: The Organization as a Reflection of its Top Managers, Academy of Management Review 9(2), 193-206.

Heckman, James J., 1995, Lessons from the Bell Curve, Journal of Political Economy 103(5), 1091-1120.

Heckman, James J., Jora Stixrud, and Sergio Urzua, 2006, The Effects of Cognitive and Noncognitive Abilities on Labor Market Outcomes and Social Behavior, Journal of Labor Economics, 24(3), 411-482.

Herrnstein, Richard J., and Charles A. Murray, 1996, The Bell Curve: Intelligence and Class Structure in American Life, Free Press.

Hiller, Nathan, Leslie DeChurch, Toshio Murase, and Daniel Doty, 2011, Searching for Outcomes of Leadership: A 25-year Review, Journal of Management 37(4), 1137-1177.

Hirshleifer, David, Angie Low, and Siew Hong Teoh, 2012, Are Overconfident CEOs Better Innovators? Journal of Finance 67(4), 1457-1498.

Johnson, W. Bruce, Robert Magee, Nandu Nagarajan, and Harry Newman, 1985, An Analysis of the Stock Price Reaction to Sudden Executive Deaths: Implications for the Managerial Labor Market, Journal of Accounting and Economics 7(1-3), 151-174.

Kaplan, Steven and Joshua Rauh, 2010, Wall Street and Main Street: What Contributes to the Rise in the Highest Incomes, Review of Financial Studies 23(3), 1004-1050.

Kaplan, Steven and Joshua Rauh, 2013, It's the Market: The Broad-Based Rise in the Return to Top Talent, Journal of Economic Perspectives 27(3), 35-55.

Kaplan, Steven, Mark Klebanov, and Morten Sorensen, 2012, Which CEO Characteristics and Abilities Matter? Journal of Finance 67(3), 973-1007.

Koehn, Nancy, 2014, Great Men, Great Pay? Why CEO Compensation is Sky High, Washington Post, June 12. 
Levine, Ross and Yona Rubinstein, 2015, Smart and Illicit: Who Becomes an Entrepreneur and Do They Earn More? University of California at Berkeley working paper.

Lieberson, Stanley, and James F. O'Connor, 1972, Leadership and Organizational Performance: A Study of Large Corporations, American Sociological Review 37(2), 117-130.

Lindqvist, Erik, 2012, Height and Leadership, Review of Economics and Statistics 94(4), 11911196.

Lindqvist, Erik, and Roine Vestman, 2011, The Labor Market Returns to Cognitive and Noncognitive Ability: Evidence from the Swedish Enlistment, American Economic Journal: Applied Economics 3(1), 101-128.

Lundborg, Petter, Paul Nystedt, and Dan-Olof Rooth, 2014, Height and Earnings: The Role of Cognitive and Noncognitive Skills, Journal of Human Resources 49(1), 141-166.

Malmendier, Ulrike and Geoffrey Tate, 2005, CEO Overconfidence and Corporate Investment, Journal of Finance 60(6), 2661-2700.

Malmendier, Ulrike and Geoffrey Tate, 2008, Who Makes Acquisitions? CEO Overconfidence and the Market's Reaction, Journal of Financial Economics 89(1), 20-43.

Malmendier, Ulrike and Geoffrey Tate, 2009, Superstar CEOs, Quarterly Journal of Economics 124(4), 1593-1638.

Malmendier, Ulrike, Geoffrey Tate, and Jon Yan, 2011, Overconfidence and Early-Life Experiences: The Effect of Managerial Traits on Corporate Financial Policies, Journal of Finance 66(5), 1687-1733.

Matsa, David, and Amalia Miller, 2014, Workforce Reductions at Women-Owned Businesses in the United States, Industrial \& Labor Relations Review 67(2), 422-452.

Mehrotra, Vikas, Randall Morck, Jungwook Shim, and Yupana Wiwattanakantang, 2013, Adoptive Expectations: Rising Sons in Japanese Family Firms, Journal of Financial Economics 108(3), 840-854.

Mueller, Holger M., and Thomas Philippon, 2011, Family Firms and Labor Relations, American Economic Journal: Macroeconomics 3(2), 218-245. 
Mullins, William, and Antoinette Schoar, 2013, How Do CEOs See Their Role? Management Philosophy and Styles in Family and Non-Family Firms, NBER working paper.

Murphy, Kevin, 1999, Executive Compensation, In Orley Ashenfelter and David Card (eds.), Handbook of Labor Economics 3B, Chapter 38, Elsevier, 2485-2557.

Murphy Kevin J., 2012, Executive Compensation: Where We Are, and How We Got There, In George Constantinides, Milton Harris, and René Stulz (eds.), Handbook of the Economics of Finance, Elsevier, forthcoming.

Murphy Kevin J., and Jan Zábojník, 2004, CEO Pay and Appointments: A Market-Based Explanation for Recent Trends, American Economic Review Papers and Proceedings 94(2), 192-196.

Murphy, Kevin J., and Jan Zábojník, 2007, Managerial Capital and the Market for CEOs, University of Southern California working paper.

Murphy, Kevin M., Andrei Shleifer, and Robert Vishny, 1991, The Allocation of Talent: Implications for Growth, Quarterly Journal of Economics 106(2), 503-530.

Olsson, Martin, and Joacim Tåg, 2015, Private Equity, Layoffs, and Job Polarization, IFN working paper.

Olsson, Ulf, 1993, Securing the Markets. Swedish Multinationals in a Historical Perspective, In Geoffrey Jones and Harm G. Schröter (eds.), The Rise of Multinationals in Continental Europe, Chapter 5, Aldershot: Edward Elgar, 99-127.

Oyer, Paul, and Scott Schaefer, 2012, Welcome to the Club: The Returns to an Elite Degree for American Lawyers, Stanford University working paper.

Pérez-González, Francisco, 2006, Inherited Control and Firm Performance, American Economic Review 96(5), 1559-1588.

Persico, Nicola, Andrew Postlewaite, and Dan Silverman, 2004, The Effect of Adolescent Experience on Labor Market Outcomes: The Case of Height, Journal of Political Economy 112(5), 1019-1053.

Philippon, Thomas and Ariell Reshef, 2012, Wages and Human Capital in the U.S. Finance Industry: 1909-2006, Quarterly Journal of Economics 127(4), 1551-1609. 
Rosenthal, Robert, 1978, Combining Results of Independent Studies, Psychological Bulletin 85(1), 185-193.

Schmidt, Frank and John Hunter, 1998, The Validity and Utility of Selection Methods in Personnel Psychology: Practical and Theoretical Implications of 85 Years of Research Findings, Psychological Bulletin 124(2), 262-274.

Schoar, Antoinette and Luo Zuo, 2011, Shaped by Booms and Busts: How the Economy Impacts CEO Careers and Management Styles, NBER working paper.

Sraer, David, and David Thesmar, 2007, Performance and Behavior of Family Firms: Evidence from the French Stock Market, Journal of the European Economic Association 5(4), 709751.

Steckel, Richard H., 1995, Stature and the Standard of Living, Journal of Economic Literature 33(4), 1903-1940.

Steckel, Richard H., 2009, Heights and Human Welfare: Recent Developments and New Directions, Explorations in Economic History 46(1), 1-23.

Terviö, Marko, 2008, The Difference That CEOs Make: An Assignment Model Approach, American Economic Review 98(3), 642-668.

Terviö, Marko, 2009, Superstars and Mediocrities: Market Failure in the Discovery of Talent, Review of Economic Studies 76(2), 829-850.

Thomas, Alan Berkeley, 1988, Does Leadership Make a Difference to Organizational Performance? Administrative Science Quarterly 33(3), 388-400.

Wai, Jonathan, 2013, Investigating America's Elite: Cognitive Ability, Education, and Sex Differences, Intelligence 41(4), 203-211.

Wai, Jonathan, 2014, Investigating the World's Rich and Powerful: Education, Cognitive Ability, and Sex Differences, Intelligence 46, 54-72.

Yermack, David, 1997, Good Timing: CEO Stock Option Awards and Company News Announcements, Journal of Finance 52(2), 449-476. 
Panel A: Traits by firm size
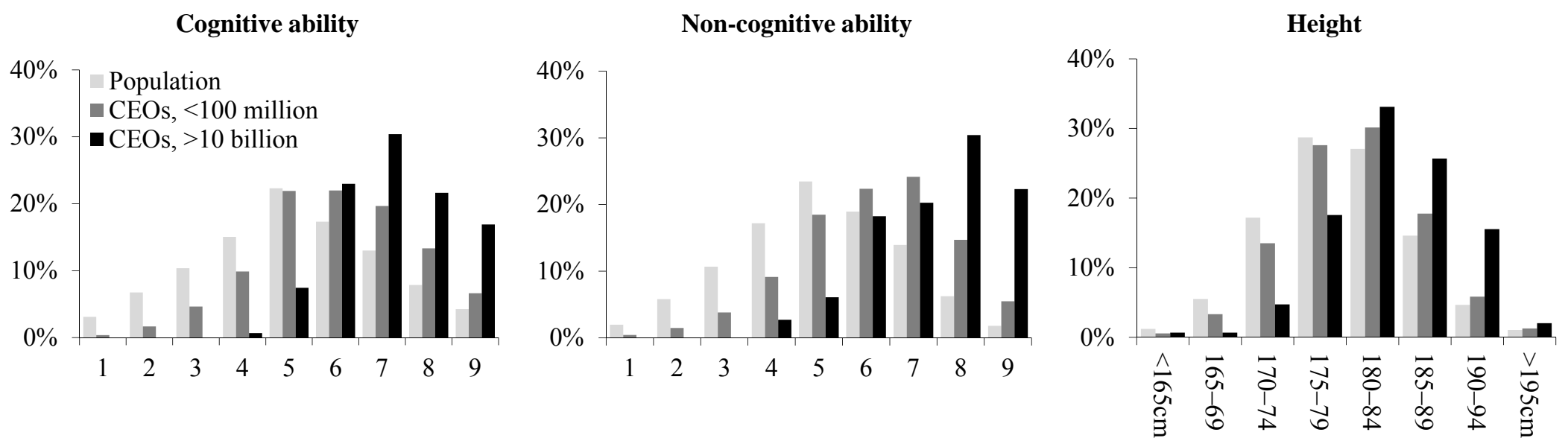

Panel B: Traits by family management
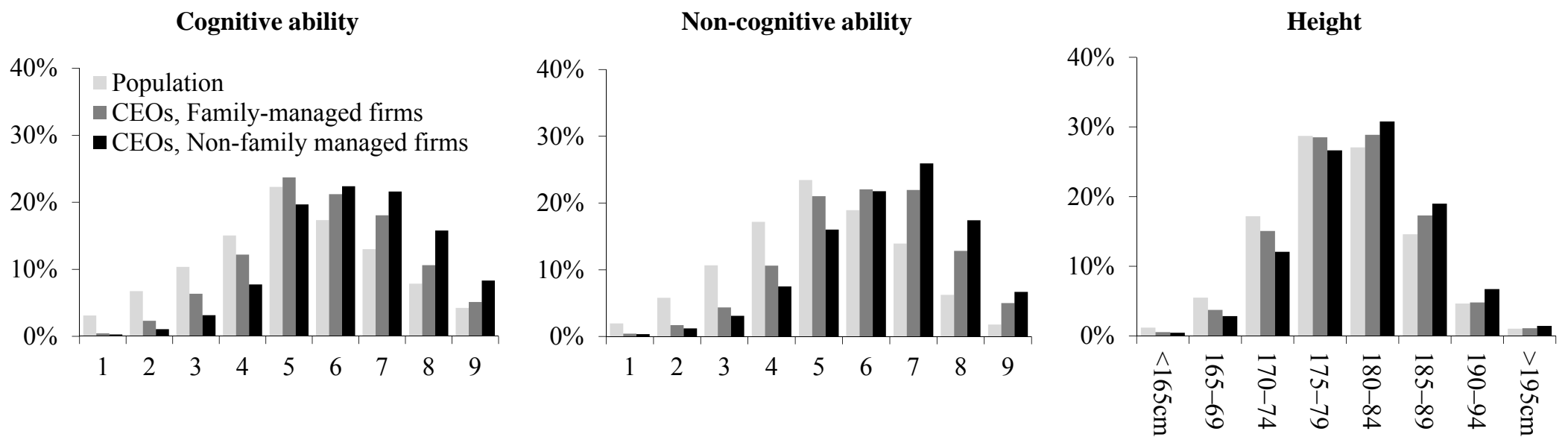

Figure 1. Distributions of personal traits of CEOs in different firm-size categories, and the population at large. The light bars indicate the population. In Panel A, the grey and black bars show the distributions for CEOs in firms with less than 100 million and more than 10 billion in total assets, respectively. The grey and black bars in Panel B report the distributions for family-managed firms and non-family managed firms, respectively. 


\section{Panel A: CEO traits and firm size}

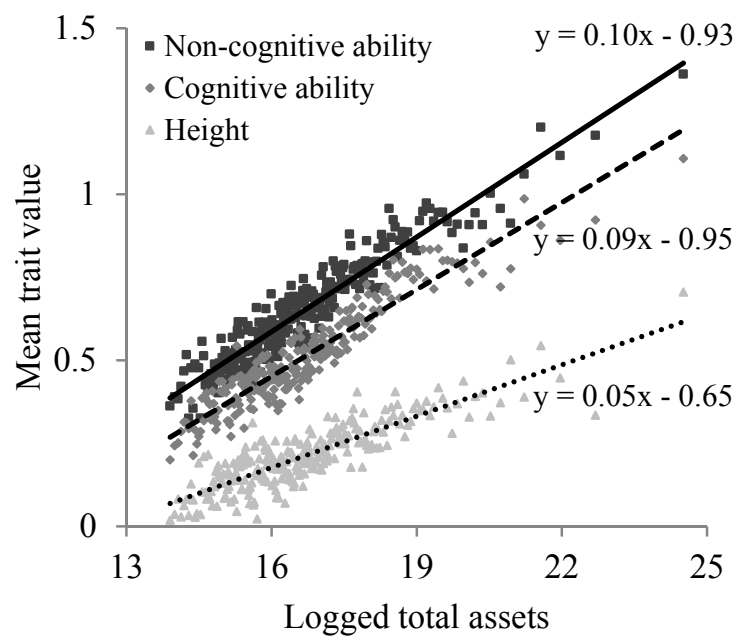

Panel B: CEO pay and firm size

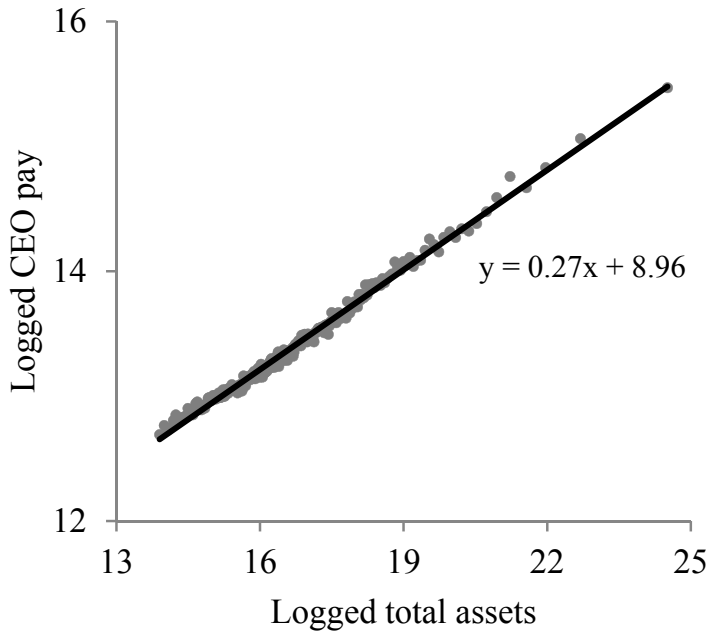

Panel C: CEO traits and CEO pay

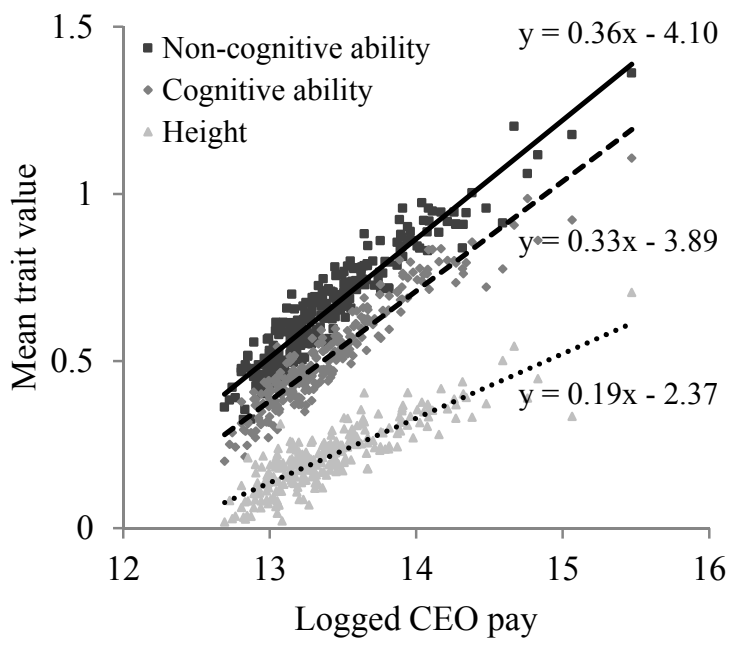

Figure 2. Relations between CEOs' traits, pay, and firm size. The graphs sort the sample of CEOs into quantiles based on their firms' total assets. Panel A plots, for each quantile, the mean of each standardized trait as a function of logged total assets of the firm. The standardization transforms the traits to have mean of zero and standard deviation of one. Panel B plots logged CEO pay against logged total assets. Panel C graphs the mean of each standardized trait as a function of logged CEO pay. Each graph also reports the regression equations from linear regressions that explain each variable on the vertical axis with each variable on the horizontal axis. 
Firms with assets less than 100 million

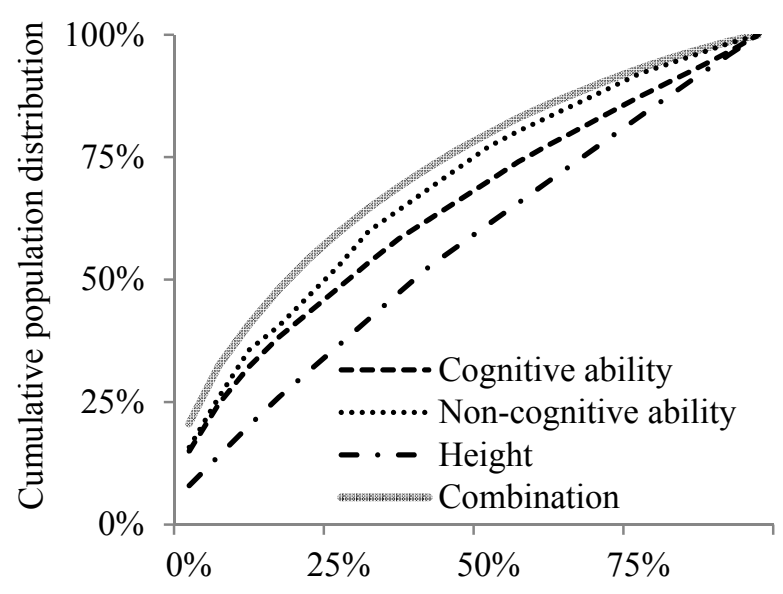

Cumulative CEO distribution
Firms with assets more than 10 billion

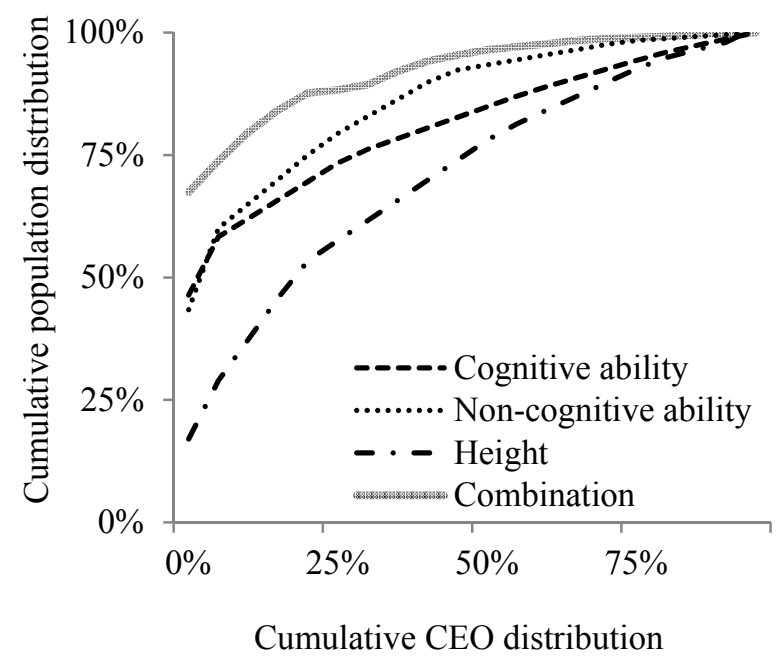

Figure 3. Cumulative distributions of CEOs' traits compared to the population at large. For each firm size category, each point in the graphs depicts the cumulative probability of each CEO trait and the combination of traits relative to the corresponding value in the population. See Table 5 for further description. 
Panel A: Distributions of CEO traits

\section{By firm size}

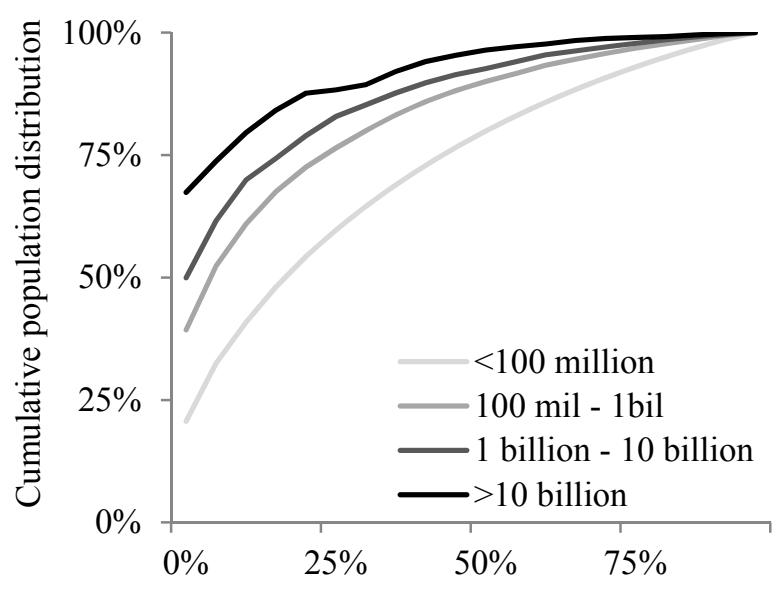

Cumulative CEO distribution
By family firm status

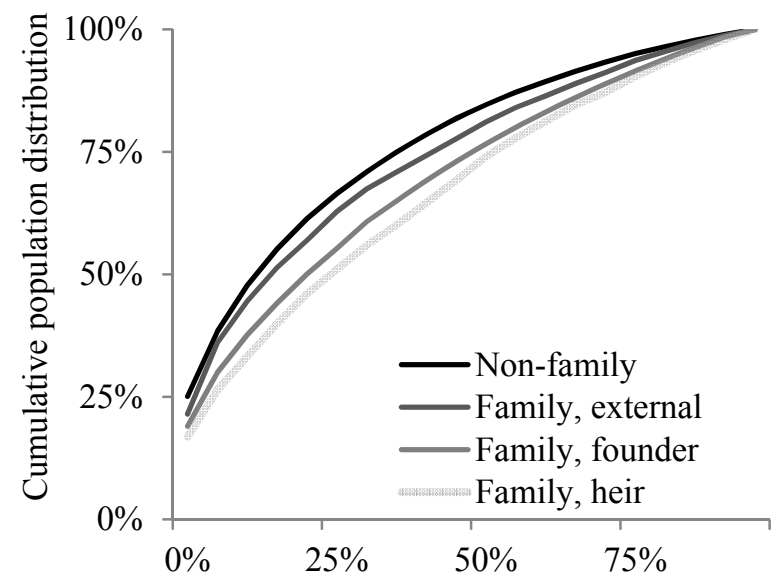

Cumulative CEO distribution

Panel B: Distributions of CEO pay

By firm size

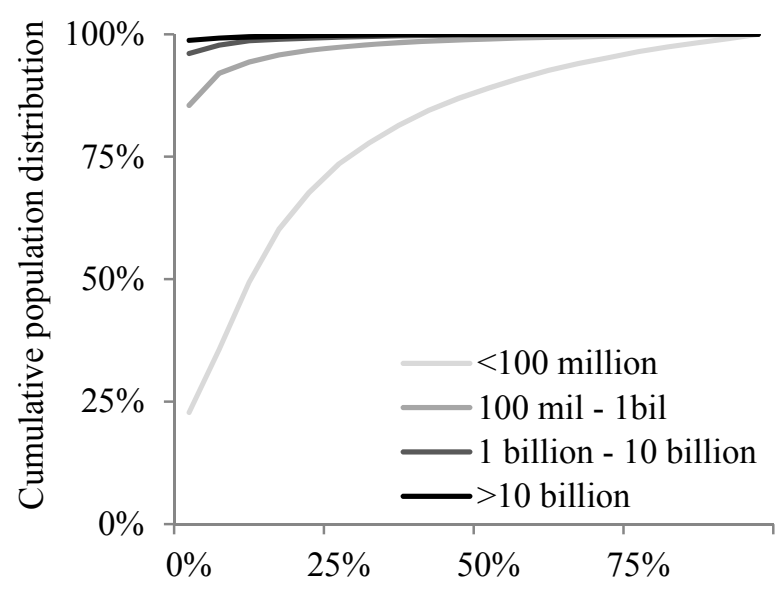

Cumulative CEO distribution
By family firm status

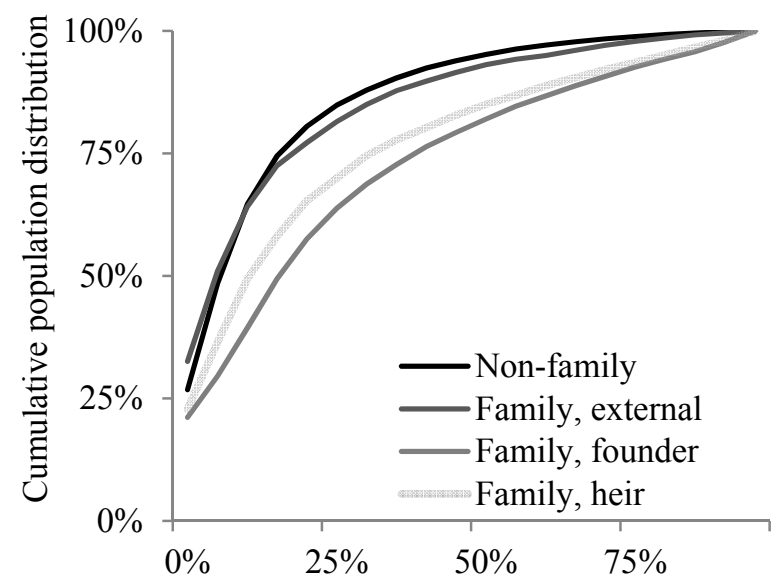

Cumulative CEO distribution

Figure 4. Cumulative distributions of CEOs' combined traits and pay compared to the population at large. Each point in the graphs in Panel A depicts the cumulative probability of attaining a CEO position based on traits by firm size and by family firm status. Panel B plots the cumulative probability of each CEO's income relative to the corresponding value in the population. See Table 5 for further description. 
Table 1

Traits for the population, for CEOs in firms of different size, and for other skilled professions

This table reports means, medians, and standard deviations of traits, the year an individual was enlisted, level of education, taxable labor income (in SEK), and, for CEOs, the total assets of the firm they manage (in SEK; 1 SEK $\approx 0.12$ USD). In Panel A, the statistics are calculated separately for the population and for medical doctors, engineers, and lawyers. Panel B reports descriptive statistics for CEOs of firms with less than 100 million, 100 million to 1 billion, 1 billion to 10 billion, and more than 10 billion in total assets. The unit of observation is an individual. The CEOs are assigned to categories according to the largest firm they have managed during the sample period 2004-10.

\begin{tabular}{|c|c|c|c|c|c|c|c|c|c|c|c|c|}
\hline \multicolumn{13}{|c|}{ Panel A: Population and skilled professions } \\
\hline & \multicolumn{3}{|c|}{ Population } & \multicolumn{3}{|c|}{ Medical doctors } & \multicolumn{3}{|c|}{ Engineers } & \multicolumn{3}{|c|}{ Lawyers } \\
\hline & Mean & $\mathrm{Sd}$ & Median & Mean & $\mathrm{Sd}$ & Median & Mean & $\mathrm{Sd}$ & Median & Mean & $\mathrm{Sd}$ & Median \\
\hline Cognitive ability & 5.15 & 1.93 & 5.00 & 7.49 & 1.35 & 8.00 & 7.11 & 1.43 & 7.00 & 6.66 & 1.42 & 7.00 \\
\hline Induction & 5.12 & 1.93 & 5.00 & 7.32 & 1.41 & 8.00 & 6.87 & 1.49 & 7.00 & 6.79 & 1.46 & 7.00 \\
\hline Verbal & 5.01 & 1.82 & 5.00 & 7.17 & 1.43 & 7.00 & 6.44 & 1.45 & 6.00 & 6.85 & 1.39 & 7.00 \\
\hline Spatial & 5.25 & 1.90 & 5.00 & 6.63 & 1.58 & 7.00 & 6.73 & 1.57 & 7.00 & 5.92 & 1.65 & 6.00 \\
\hline Technical & 4.96 & 1.88 & 5.00 & 6.67 & 1.63 & 7.00 & 6.81 & 1.57 & 7.00 & 5.64 & 1.63 & 6.00 \\
\hline Non-cognitive ability & 5.09 & 1.74 & 5.00 & 6.37 & 1.71 & 7.00 & 5.89 & 1.51 & 6.00 & 6.13 & 1.63 & 6.00 \\
\hline Height (cm) & 179.1 & 6.54 & 179.0 & 181.0 & 6.34 & 181.0 & 180.5 & 6.44 & 180.0 & 180.7 & 6.27 & 181.0 \\
\hline Enlistment year & 1983 & 7.69 & 1983 & 1982 & 8.08 & 1981 & 1986 & 7.28 & 1988 & 1984 & 7.82 & 1985 \\
\hline \multicolumn{13}{|l|}{ Level of education } \\
\hline Basic, less than 9 years & $1.0 \%$ & $10.1 \%$ & $0.0 \%$ & $0.0 \%$ & $0.0 \%$ & $0.0 \%$ & $0.0 \%$ & $0.9 \%$ & $0.0 \%$ & $0.0 \%$ & $0.0 \%$ & $0.0 \%$ \\
\hline Basic, 9 to 10 years & $12.2 \%$ & $32.7 \%$ & $0.0 \%$ & $0.0 \%$ & $0.0 \%$ & $0.0 \%$ & $0.0 \%$ & $0.0 \%$ & $0.0 \%$ & $0.0 \%$ & $0.0 \%$ & $0.0 \%$ \\
\hline Vocational or high school & $51.8 \%$ & $50.0 \%$ & $100.0 \%$ & $0.0 \%$ & $0.0 \%$ & $0.0 \%$ & $0.0 \%$ & $0.0 \%$ & $0.0 \%$ & $0.0 \%$ & $0.0 \%$ & $0.0 \%$ \\
\hline College or university & $33.5 \%$ & $47.2 \%$ & $0.0 \%$ & $72.3 \%$ & $44.8 \%$ & $100.0 \%$ & $92.2 \%$ & $26.8 \%$ & $100.0 \%$ & $98.2 \%$ & $13.2 \%$ & $100.0 \%$ \\
\hline Doctoral & $1.5 \%$ & $12.0 \%$ & $0.0 \%$ & $27.7 \%$ & $44.8 \%$ & $0.0 \%$ & $7.8 \%$ & $26.8 \%$ & $0.0 \%$ & $1.8 \%$ & $13.2 \%$ & $0.0 \%$ \\
\hline Income (thousand) & 400 & 370 & 358 & 834 & 357 & 815 & 572 & 241 & 531 & 761 & 567 & 618 \\
\hline Number of individuals & \multicolumn{3}{|c|}{$1,268,176$} & \multicolumn{3}{|c|}{9,348} & \multicolumn{3}{|c|}{39,567} & \multicolumn{3}{|c|}{6,192} \\
\hline
\end{tabular}




\begin{tabular}{|c|c|c|c|c|c|c|c|c|c|c|c|c|}
\hline \multicolumn{13}{|c|}{ Panel B: CEOs by firm size } \\
\hline & \multicolumn{3}{|c|}{ CEOs, $<100$ million } & \multicolumn{3}{|c|}{$\begin{array}{l}\text { CEOs, } 100 \text { million }-1 \\
\text { billion }\end{array}$} & \multicolumn{3}{|c|}{ CEOs, 1 billion -10 billion } & \multicolumn{3}{|c|}{ CEOs, $>10$ billion } \\
\hline & Mean & $\mathrm{Sd}$ & Median & Mean & $\mathrm{Sd}$ & Median & Mean & $\mathrm{Sd}$ & Median & Mean & $\mathrm{Sd}$ & Median \\
\hline Cognitive ability & 6.02 & 1.65 & 6.00 & 6.60 & 1.48 & 7.00 & 6.84 & 1.41 & 7.00 & 7.16 & 1.21 & 7.00 \\
\hline Induction & 5.95 & 1.68 & 6.00 & 6.55 & 1.53 & 7.00 & 6.87 & 1.44 & 7.00 & 7.06 & 1.27 & 7.00 \\
\hline Verbal & 5.71 & 1.58 & 6.00 & 6.30 & 1.49 & 6.00 & 6.63 & 1.46 & 7.00 & 6.99 & 1.27 & 7.00 \\
\hline Spatial & 5.82 & 1.73 & 6.00 & 6.12 & 1.66 & 6.00 & 6.21 & 1.58 & 6.00 & 6.48 & 1.47 & 7.00 \\
\hline Technical & 5.59 & 1.71 & 6.00 & 5.86 & 1.67 & 6.00 & 5.91 & 1.59 & 6.00 & 6.08 & 1.71 & 6.00 \\
\hline Non-cognitive ability & 6.14 & 1.59 & 6.00 & 6.67 & 1.47 & 7.00 & 6.93 & 1.42 & 7.00 & 7.36 & 1.32 & 8.00 \\
\hline Height $(\mathrm{cm})$ & 180.3 & 6.25 & 180.0 & 181.4 & 6.17 & 181.0 & 181.6 & 5.94 & 182.0 & 183.5 & 5.96 & 183.0 \\
\hline Enlistment year & 1982 & 6.92 & 1982 & 1980 & 6.27 & 1980 & 1979 & 5.83 & 1978 & 1977 & 5.35 & 1976 \\
\hline \multicolumn{13}{|l|}{ Level of education } \\
\hline Basic, less than 9 years & $0.4 \%$ & $6.4 \%$ & $0.0 \%$ & $0.2 \%$ & $3.9 \%$ & $0.0 \%$ & $0.0 \%$ & $0.0 \%$ & $0.0 \%$ & $0.7 \%$ & $8.2 \%$ & $0.0 \%$ \\
\hline Basic, 9 to 10 years & $8.5 \%$ & $27.9 \%$ & $0.0 \%$ & $2.6 \%$ & $16.0 \%$ & $0.0 \%$ & $0.7 \%$ & $8.6 \%$ & $0.0 \%$ & $0.0 \%$ & $0.0 \%$ & $0.0 \%$ \\
\hline Vocational or high school & $41.5 \%$ & $49.3 \%$ & $0.0 \%$ & $23.1 \%$ & $42.2 \%$ & $0.0 \%$ & $11.9 \%$ & $32.4 \%$ & $0.0 \%$ & $4.7 \%$ & $21.3 \%$ & $0.0 \%$ \\
\hline College or university & $48.2 \%$ & $50.0 \%$ & $0.0 \%$ & $72.0 \%$ & $44.9 \%$ & $100.0 \%$ & $86.0 \%$ & $34.7 \%$ & $100.0 \%$ & $86.5 \%$ & $34.3 \%$ & $100.0 \%$ \\
\hline Doctoral & $1.4 \%$ & $11.7 \%$ & $0.0 \%$ & $2.1 \%$ & $14.2 \%$ & $0.0 \%$ & $1.3 \%$ & $11.5 \%$ & $0.0 \%$ & $8.1 \%$ & $27.4 \%$ & $0.0 \%$ \\
\hline Income (thousand) & 752 & 635 & 626 & 1,773 & 1,601 & 1,349 & 3,402 & 3,263 & 2,448 & 6,219 & 5,362 & 4,159 \\
\hline Assets of the firm (million) & 21.3 & 27.1 & 12.1 & 312 & 287 & 216 & 3,021 & 2,594 & 2,239 & 50,100 & 94,100 & 18,700 \\
\hline Number of individuals & & 21,937 & & & 3,266 & & & 672 & & & 148 & \\
\hline
\end{tabular}


Table 2

CEO traits in family and non-family firms

Panel A reports descriptive statistics for firms that are and are not in family ownership. Family firms are further divided into companies where the CEO is not a member of the family, the CEO is the founder, and the CEO is the heir of the founder. The unit of observation is an individual. The CEOs are assigned to categories according to the largest firm they have managed during the sample period 2004-10. Panel B regresses each trait on firm characteristics. Three dummies indicate family firms (non-family firm omitted) and logged total assets measures firm size. Columns 1-2 report regressions of the standardized value of cognitive ability. The first specification includes dummies for each year and each enlistment year. The second specification adds fixed effects for industries. Columns 3-4 and 5-6 follow the same structure for standardized values of non-cognitive ability and height, respectively. The $t$-values reported in parentheses are based on standard errors that allow for clustering at the CEO level. The $p$-values in brackets report the tests of equality for each pairing of the family-firm coefficients.

\begin{tabular}{|c|c|c|c|c|c|c|c|c|c|c|c|c|}
\hline \multicolumn{13}{|c|}{ Panel A: Descriptive statistics of CEOs by family ownership } \\
\hline & \multicolumn{3}{|c|}{ Non-family firm CEOs } & \multicolumn{3}{|c|}{ Family firm, external CEO } & \multicolumn{3}{|c|}{ Family firm, founder CEO } & \multicolumn{3}{|c|}{ Family firm, heir CEO } \\
\hline & Mean & $\mathrm{Sd}$ & Median & Mean & $\mathrm{Sd}$ & Median & Mean & $\mathrm{Sd}$ & Median & Mean & $\mathrm{Sd}$ & Median \\
\hline Cognitive ability & 6.29 & 1.60 & 6.00 & 6.15 & 1.58 & 6.00 & 5.77 & 1.67 & 6.00 & 5.73 & 1.67 & 6.00 \\
\hline Induction & 6.23 & 1.63 & 6.00 & 6.16 & 1.65 & 6.00 & 5.67 & 1.70 & 6.00 & 5.66 & 1.69 & 6.00 \\
\hline Verbal & 5.99 & 1.56 & 6.00 & 5.83 & 1.49 & 6.00 & 5.47 & 1.61 & 5.00 & 5.39 & 1.58 & 5.00 \\
\hline Spatial & 5.96 & 1.70 & 6.00 & 5.84 & 1.69 & 6.00 & 5.70 & 1.77 & 6.00 & 5.73 & 1.73 & 6.00 \\
\hline Technical & 5.73 & 1.70 & 6.00 & 5.60 & 1.68 & 6.00 & 5.45 & 1.72 & 5.00 & 5.40 & 1.72 & 5.00 \\
\hline Non-cognitive ability & 6.35 & 1.57 & 7.00 & 6.19 & 1.55 & 6.00 & 6.00 & 1.61 & 6.00 & 5.90 & 1.60 & 6.00 \\
\hline Height (cm) & 180.8 & 6.2 & 181.0 & 180.5 & 6.3 & 180.0 & 179.9 & 6.2 & 180.0 & 179.9 & 6.3 & 180.0 \\
\hline Enlistment year & 1981 & 1907 & 1981 & 1982 & 1907 & 1982 & 1981 & 1907 & 1981 & 1980 & 1908 & 1979 \\
\hline \multicolumn{13}{|l|}{ Level of education } \\
\hline Basic, less than 9 years & $0.2 \%$ & $4.2 \%$ & $0.0 \%$ & $0.4 \%$ & $6.3 \%$ & $0.0 \%$ & $0.6 \%$ & $7.5 \%$ & $0.0 \%$ & $1.7 \%$ & $12.8 \%$ & $0.0 \%$ \\
\hline Basic, 9 to 10 years & $5.4 \%$ & $22.6 \%$ & $0.0 \%$ & $6.3 \%$ & $24.2 \%$ & $0.0 \%$ & $11.6 \%$ & $32.0 \%$ & $0.0 \%$ & $15.0 \%$ & $35.7 \%$ & $0.0 \%$ \\
\hline Vocational or high school & $33.1 \%$ & $47.1 \%$ & $0.0 \%$ & $36.9 \%$ & $48.3 \%$ & $0.0 \%$ & $48.9 \%$ & $50.0 \%$ & $0.0 \%$ & $50.8 \%$ & $50.0 \%$ & $100.0 \%$ \\
\hline College or university & $59.3 \%$ & $49.1 \%$ & $100.0 \%$ & $55.4 \%$ & $49.7 \%$ & $100.0 \%$ & $38.3 \%$ & $48.6 \%$ & $0.0 \%$ & $32.4 \%$ & $46.8 \%$ & $0.0 \%$ \\
\hline Doctoral & $2.0 \%$ & $14.1 \%$ & $0.0 \%$ & $1.0 \%$ & $9.9 \%$ & $0.0 \%$ & $0.6 \%$ & $8.0 \%$ & $0.0 \%$ & $0.1 \%$ & $3.7 \%$ & $0.0 \%$ \\
\hline Income (thousand) & 1,151 & 1,438 & 793 & 985 & 1,272 & 719 & 615 & 427 & 525 & 642 & 456 & 545 \\
\hline Assets of the firm (million) & 600 & 9,901 & 20 & 409 & 5,712 & 21 & 38 & 287 & 11 & 71 & 711 & 16 \\
\hline Number of individuals & & 16,609 & & & 1,503 & & & 6,417 & & & 1,494 & \\
\hline
\end{tabular}




\begin{tabular}{|c|c|c|c|c|c|c|}
\hline \multicolumn{7}{|c|}{ Panel B: Regressions of traits on family company indicators and firm size } \\
\hline \multirow{2}{*}{$\begin{array}{l}\text { Dependent variable } \\
\text { Specification }\end{array}$} & \multicolumn{2}{|c|}{ Cognitive ability } & \multicolumn{2}{|c|}{ Non-cognitive ability } & \multicolumn{2}{|c|}{ Height } \\
\hline & 1 & 2 & 3 & 4 & 5 & 6 \\
\hline Family, external & $\begin{array}{l}-0.075 \\
(-2.96)\end{array}$ & $\begin{array}{l}-0.034 \\
(-1.38)\end{array}$ & $\begin{array}{l}-0.094 \\
(-3.42)\end{array}$ & $\begin{array}{l}-0.066 \\
(-2.45)\end{array}$ & $\begin{array}{l}-0.032 \\
(-1.04)\end{array}$ & $\begin{array}{l}-0.017 \\
(-0.55)\end{array}$ \\
\hline Family, founder & $\begin{array}{r}-0.226 \\
(-16.21)\end{array}$ & $\begin{array}{l}-0.115 \\
(-8.24)\end{array}$ & $\begin{array}{l}-0.120 \\
(-8.03)\end{array}$ & $\begin{array}{l}-0.049 \\
(-3.20)\end{array}$ & $\begin{array}{l}-0.095 \\
(-5.97)\end{array}$ & $\begin{array}{l}-0.065 \\
(-4.02)\end{array}$ \\
\hline Family, heir & $\begin{array}{r}-0.271 \\
(-10.23)\end{array}$ & $\begin{array}{l}-0.145 \\
(-5.49)\end{array}$ & $\begin{array}{l}-0.226 \\
(-7.95)\end{array}$ & $\begin{array}{l}-0.138 \\
(-4.79)\end{array}$ & $\begin{array}{l}-0.092 \\
(-3.03)\end{array}$ & $\begin{array}{l}-0.057 \\
(-1.85)\end{array}$ \\
\hline Total assets & $\begin{array}{r}0.069 \\
(20.56)\end{array}$ & $\begin{array}{r}0.073 \\
(20.89)\end{array}$ & $\begin{array}{r}0.088 \\
(23.59)\end{array}$ & $\begin{array}{r}0.096 \\
(24.30)\end{array}$ & $\begin{array}{r}0.049 \\
(11.99)\end{array}$ & $\begin{array}{r}0.050 \\
(11.31)\end{array}$ \\
\hline Tests of coeff., $p$-values & & & & & & \\
\hline External $=$ founder & {$[<0.01]$} & {$[<0.01]$} & [0.38] & {$[0.56]$} & {$[0.06]$} & [0.15] \\
\hline External $=$ heir & {$[<0.01]$} & {$[<0.01]$} & {$[<0.01]$} & {$[0.06]$} & {$[0.16]$} & {$[0.35]$} \\
\hline Founder $=$ heir & {$[0.11]$} & {$[0.28]$} & {$[<0.01]$} & {$[<0.01]$} & [0.93] & {$[0.79]$} \\
\hline Controls & & & & & & \\
\hline Year & Yes & Yes & Yes & Yes & Yes & Yes \\
\hline Enlistment year & Yes & Yes & Yes & Yes & Yes & Yes \\
\hline Industry fixed effects & No & Yes & No & Yes & No & Yes \\
\hline Mean dependent variable & 0.51 & 0.51 & 0.65 & 0.65 & 0.21 & 0.21 \\
\hline Adjusted $R^{2}$ & 0.053 & 0.112 & 0.040 & 0.061 & 0.013 & 0.018 \\
\hline Number of observations & 96,815 & 96,815 & 96,815 & 96,815 & 96,815 & 96,815 \\
\hline
\end{tabular}


Table 3

\section{Correlations of CEOs' traits with firm size}

The regressions in this table correlate firm size with the standardized values of CEO traits. The regressions are run separately by family firm status. Columns $1-3$ report regressions for non-family firms. The first specification includes dummies for each year and each enlistment year. The second specification adds fixed effects for industries and the third specification adds dummies for five levels and eight fields of education. Columns 4-6, 7-9, and 10-12 follow the same structure for family firms managed by a professional CEO, the founder, or a later-generation family member, respectively. The $t$-values reported in parentheses are based on standard errors that allow for clustering at the CEO level.

\begin{tabular}{|c|c|c|c|c|c|c|c|c|c|c|c|c|}
\hline \multirow{3}{*}{$\begin{array}{l}\text { Dependent variable } \\
\text { Specification }\end{array}$} & \multicolumn{12}{|c|}{ Logged total assets } \\
\hline & \multicolumn{3}{|c|}{ Non-family firms } & \multicolumn{3}{|c|}{ Family firms, external } & \multicolumn{3}{|c|}{ Family firms, founder } & \multicolumn{3}{|c|}{ Family firms, heir } \\
\hline & 1 & 2 & 3 & 4 & 5 & 6 & 7 & 8 & 9 & 10 & 11 & 12 \\
\hline \multirow[t]{2}{*}{ Cognitive ability } & 0.217 & 0.208 & 0.066 & 0.129 & 0.154 & 0.048 & 0.104 & 0.113 & 0.061 & 0.110 & 0.097 & 0.055 \\
\hline & $(12.43)$ & $(12.79)$ & $(3.88)$ & $(2.28)$ & $(3.12)$ & $(0.97)$ & $(5.52)$ & $(6.18)$ & $(3.16)$ & $(2.73)$ & $(2.52)$ & $(1.35)$ \\
\hline \multirow{2}{*}{ Non-cognitive ability } & 0.296 & 0.272 & 0.223 & 0.094 & 0.128 & 0.041 & 0.081 & 0.089 & 0.064 & 0.057 & 0.061 & 0.042 \\
\hline & $(17.79)$ & $(18.32)$ & $(15.27)$ & $(1.70)$ & $(2.67)$ & $(0.87)$ & $(4.59)$ & $(5.28)$ & $(3.81)$ & $(1.47)$ & $(1.65)$ & $(1.09)$ \\
\hline \multirow[t]{2}{*}{ Height } & 0.130 & 0.110 & 0.093 & 0.150 & 0.152 & 0.125 & 0.040 & 0.041 & 0.037 & -0.022 & -0.029 & -0.038 \\
\hline & $(8.49)$ & $(7.93)$ & $(6.94)$ & $(3.49)$ & $(3.95)$ & $(3.28)$ & $(2.43)$ & $(2.62)$ & $(2.42)$ & $(-0.59)$ & $(-0.79)$ & $(-1.03)$ \\
\hline \multicolumn{13}{|l|}{ Controls } \\
\hline Year & Yes & Yes & Yes & Yes & Yes & Yes & Yes & Yes & Yes & Yes & Yes & Yes \\
\hline Enlistment year & Yes & Yes & Yes & Yes & Yes & Yes & Yes & Yes & Yes & Yes & Yes & Yes \\
\hline Industry fixed effects & No & Yes & Yes & No & Yes & Yes & No & Yes & Yes & No & Yes & Yes \\
\hline Education level and field & No & No & Yes & No & No & Yes & No & No & Yes & No & No & Yes \\
\hline Mean dependent variable & 10.06 & 10.06 & 10.06 & 9.85 & 9.85 & 9.85 & 9.22 & 9.22 & 9.22 & 9.61 & 9.61 & 9.61 \\
\hline Adjusted $R^{2}$ & 0.091 & 0.241 & 0.283 & 0.063 & 0.212 & 0.262 & 0.021 & 0.119 & 0.147 & 0.031 & 0.124 & 0.143 \\
\hline Number of observations & 61,437 & 61,437 & 61,437 & 4,207 & 4,207 & 4,207 & 25,427 & 25,427 & 25,427 & 5,744 & 5,744 & 5,744 \\
\hline
\end{tabular}




\section{Table 4}

\section{Contribution of traits to attaining a CEO position}

This table reports results from linear probability models which explain the dummy for CEOs with standardized values of cognitive and non-cognitive ability, and height. Columns 1-3 in Panel A add each trait separately. They, along with all other specifications, also include dummies for each year and each enlistment year. Column 4 includes all traits in the regression. Column 5 adds dummies for five levels and eight fields of education. Column 6 further includes fixed effects for brothers who are born to the same mother. Panel B repeats the same structure for the four subcomponents of cognitive ability. The $t$-values reported in parentheses are based on standard errors that allow for clustering at the individual level or at the family level in the family fixed effects specifications. In Panel A, the number of observations is $8,760,402$ in all but the family fixed effects specifications in which missing family links reduce the sample size by 94,049 observations. The corresponding numbers in Panel B are 84,251 and 7,709,018 because the subscores are missing for some individuals. The mean dependent variable and the coefficients are multiplied by one hundred.

\begin{tabular}{|c|c|c|c|c|c|c|}
\hline \multicolumn{7}{|c|}{ Panel A: Baseline regressions } \\
\hline \multirow{2}{*}{$\begin{array}{l}\text { Dependent variable } \\
\text { Specification }\end{array}$} & \multicolumn{6}{|c|}{ CEO dummy } \\
\hline & 1 & 2 & 3 & 4 & 5 & 6 \\
\hline \multirow[t]{2}{*}{ Cognitive ability } & 0.552 & & & 0.307 & 0.227 & 0.246 \\
\hline & $(71.09)$ & & & $(38.51)$ & $(24.91)$ & $(10.10)$ \\
\hline \multirow[t]{2}{*}{ Non-cognitive ability } & & 0.724 & & 0.591 & 0.552 & 0.380 \\
\hline & & $(81.81)$ & & $(64.64)$ & $(60.35)$ & $(17.31)$ \\
\hline \multirow[t]{2}{*}{ Height } & & & 0.244 & 0.122 & 0.112 & 0.137 \\
\hline & & & $(31.09)$ & $(15.56)$ & $(14.36)$ & $(5.77)$ \\
\hline \multicolumn{7}{|l|}{ Controls } \\
\hline Year & Yes & Yes & Yes & Yes & Yes & Yes \\
\hline Enlistment year & Yes & Yes & Yes & Yes & Yes & Yes \\
\hline Education & No & No & No & No & Yes & Yes \\
\hline Family fixed effects & No & No & No & No & No & Yes \\
\hline Mean dependent variable & 1.113 & 1.113 & 1.113 & 1.113 & 1.113 & 1.111 \\
\hline Adjusted $R^{2}$ & 0.004 & 0.006 & 0.002 & 0.007 & 0.010 & 0.501 \\
\hline Number of observations & $8,760,402$ & $8,760,402$ & $8,760,402$ & $8,760,402$ & $8,760,402$ & $8,666,353$ \\
\hline
\end{tabular}




\begin{tabular}{|c|c|c|c|c|c|c|c|}
\hline \multicolumn{8}{|c|}{ Panel B. Components of cognitive ability } \\
\hline Dependent variable & & & & $\mathrm{O}$ dumn & & & \\
\hline Specification & 1 & 2 & 3 & 4 & 5 & 6 & 7 \\
\hline Induction & $\begin{array}{r}0.588 \\
(67.32)\end{array}$ & & & & $\begin{array}{r}0.245 \\
(17.26)\end{array}$ & $\begin{array}{r}0.153 \\
(10.70)\end{array}$ & $\begin{array}{c}0.156 \\
(4.62)\end{array}$ \\
\hline Verbal & & $\begin{array}{r}0.530 \\
(61.38)\end{array}$ & & & $\begin{array}{c}0.121 \\
(9.37)\end{array}$ & $\begin{array}{r}0.070 \\
(5.29)\end{array}$ & $\begin{array}{l}0.122 \\
(3.87)\end{array}$ \\
\hline Spatial & & & $\begin{array}{r}0.387 \\
(45.81)\end{array}$ & & $\begin{array}{l}-0.009 \\
(-0.76)\end{array}$ & $\begin{array}{l}-0.011 \\
(-0.99)\end{array}$ & $\begin{array}{l}-0.010 \\
(-0.38)\end{array}$ \\
\hline Technical & & & & $\begin{array}{r}0.444 \\
(51.32)\end{array}$ & $\begin{array}{c}0.038 \\
(3.20)\end{array}$ & $\begin{array}{c}0.074 \\
(6.17)\end{array}$ & $\begin{array}{l}0.082 \\
(2.78)\end{array}$ \\
\hline Non-cognitive ability & & & & & $\begin{array}{r}0.625 \\
(61.43)\end{array}$ & $\begin{array}{r}0.587 \\
(57.76)\end{array}$ & $\begin{array}{r}0.391 \\
(15.67)\end{array}$ \\
\hline Height & & & & & $\begin{array}{r}0.127 \\
(14.60)\end{array}$ & $\begin{array}{r}0.117 \\
(13.52)\end{array}$ & $\begin{array}{r}0.147 \\
(5.44)\end{array}$ \\
\hline Controls & & & & & & & \\
\hline Year & Yes & Yes & Yes & Yes & Yes & Yes & Yes \\
\hline Enlistment year & Yes & Yes & Yes & Yes & Yes & Yes & Yes \\
\hline Education & No & No & No & No & No & Yes & Yes \\
\hline Family fixed effects & No & No & No & No & No & No & Yes \\
\hline Mean dependent variable & 1.195 & 1.195 & 1.195 & 1.195 & 1.195 & 1.195 & 1.193 \\
\hline Adjusted $R^{2}$ & 0.004 & 0.003 & 0.002 & 0.003 & 0.007 & 0.008 & 0.514 \\
\hline
\end{tabular}


Table 5

\section{Fraction of population dominated by CEOs}

The table reports the fraction of the population that is dominated by CEOs according to their personal traits. The analysis considers each trait separately and in combination with the other traits. Panel A compares, separately for small and large firms, each trait to the population by calculating the proportion of the population that is dominated by CEOs at different parts of the CEOs' trait distribution. The results have been smoothed by means of interpolation; see the text for additional details. Panel B predicts, for each individual, the probability of attaining a CEO position based on the regression in Column 4 of Table 2 Panel A. The predicted probability then determines the proportion of the population a $\mathrm{CEO}$ dominates. Panel $\mathrm{C}$ reports the occupational distribution of the individuals who dominate the median CEO in each firm-size category. A skill level is attributed to each occupation using the mapping of the ISCO88 standard of occupations into the ISCED-76 classification of education. The management category includes corporate management only; non-profit management is excluded. Academics are in the teaching category. The number of observations in Panel C is less than that implied by Panel B because occupational codes are not available for all individuals. Panel D reports the population dominated by CEOs according to taxable labor income. Panels B and D calculate the cumulative probabilities separately for four firm-size categories and by family firm status.

\begin{tabular}{|c|c|c|c|c|c|c|c|c|}
\hline \multicolumn{9}{|c|}{ Panel A: Fraction of population dominated by CEOs' traits, by firm size } \\
\hline & \multicolumn{4}{|c|}{$<100$ million } & \multicolumn{4}{|c|}{$>10$ billion } \\
\hline & $\begin{array}{l}\text { Cognitive } \\
\text { ability }\end{array}$ & \multicolumn{2}{|c|}{$\begin{array}{l}\text { Non-cognitive } \\
\text { ability }\end{array}$} & Height & $\begin{array}{l}\text { Cognitive } \\
\text { ability }\end{array}$ & \multicolumn{2}{|c|}{$\begin{array}{c}\text { Non-cognitive } \\
\text { ability }\end{array}$} & Height \\
\hline $5 \%$ & $15.0 \%$ & \multicolumn{2}{|c|}{$15.8 \%$} & $8.0 \%$ & $46.4 \%$ & \multicolumn{2}{|c|}{$43.5 \%$} & $17.0 \%$ \\
\hline $25 \%$ & $43.4 \%$ & \multicolumn{2}{|c|}{$46.8 \%$} & $31.4 \%$ & $69.6 \%$ & \multicolumn{2}{|c|}{$75.0 \%$} & $53.4 \%$ \\
\hline $50 \%$ & $66.2 \%$ & \multicolumn{2}{|c|}{$72.9 \%$} & $57.0 \%$ & $82.7 \%$ & \multicolumn{2}{|c|}{$92.4 \%$} & $73.9 \%$ \\
\hline $75 \%$ & $84.0 \%$ & \multicolumn{2}{|c|}{$89.0 \%$} & $78.8 \%$ & $92.5 \%$ & \multicolumn{2}{|c|}{$97.6 \%$} & $89.8 \%$ \\
\hline $90 \%$ & $93.3 \%$ & \multicolumn{2}{|c|}{$96.1 \%$} & $91.7 \%$ & $97.3 \%$ & \multicolumn{2}{|c|}{$99.2 \%$} & $96.5 \%$ \\
\hline $95 \%$ & $96.5 \%$ & \multicolumn{2}{|c|}{$98.2 \%$} & $95.8 \%$ & $98.7 \%$ & \multicolumn{2}{|c|}{$99.6 \%$} & $98.0 \%$ \\
\hline $100 \%$ & $100.0 \%$ & \multicolumn{2}{|c|}{$100.0 \%$} & $100.0 \%$ & $100.0 \%$ & \multicolumn{2}{|c|}{$100.0 \%$} & $101.0 \%$ \\
\hline \multicolumn{9}{|c|}{ Panel B: Fraction of population dominated by CEOs' combinations of traits, by firm size, and by family firm status } \\
\hline & \multicolumn{4}{|c|}{ CEOs by firm size } & \multicolumn{4}{|c|}{ CEOs by family firm status } \\
\hline & $<100$ mil & $\begin{array}{l}100 \text { mil - } \\
1 \text { bil }\end{array}$ & $\begin{array}{c}1 \text { bil }-10 \\
\text { bil }\end{array}$ & $>10$ bil & $\begin{array}{l}\text { Non- } \\
\text { family }\end{array}$ & $\begin{array}{l}\text { Family, } \\
\text { external }\end{array}$ & $\begin{array}{l}\text { Family, } \\
\text { founder }\end{array}$ & $\begin{array}{l}\text { Family, } \\
\text { heir }\end{array}$ \\
\hline $5 \%$ & $20.6 \%$ & $39.3 \%$ & $49.9 \%$ & $67.4 \%$ & $25.1 \%$ & $21.5 \%$ & $19.0 \%$ & $16.9 \%$ \\
\hline $25 \%$ & $54.3 \%$ & $72.5 \%$ & $79.0 \%$ & $87.7 \%$ & $61.3 \%$ & $57.0 \%$ & $50.0 \%$ & $46.0 \%$ \\
\hline $50 \%$ & $76.6 \%$ & $88.2 \%$ & $91.4 \%$ & $95.4 \%$ & $81.8 \%$ & $77.7 \%$ & $73.1 \%$ & $69.2 \%$ \\
\hline $75 \%$ & $90.8 \%$ & $95.8 \%$ & $97.1 \%$ & $98.8 \%$ & $93.3 \%$ & $91.2 \%$ & $88.9 \%$ & $87.2 \%$ \\
\hline $90 \%$ & $96.9 \%$ & $98.6 \%$ & $99.1 \%$ & $99.5 \%$ & $97.8 \%$ & $97.3 \%$ & $96.3 \%$ & $95.8 \%$ \\
\hline $95 \%$ & $98.6 \%$ & $99.4 \%$ & $99.6 \%$ & $99.8 \%$ & $99.0 \%$ & $98.8 \%$ & $98.5 \%$ & $97.9 \%$ \\
\hline $100 \%$ & $100.0 \%$ & $100.0 \%$ & $100.0 \%$ & $100.0 \%$ & $100.0 \%$ & $100.0 \%$ & $100.0 \%$ & $100.0 \%$ \\
\hline
\end{tabular}




\begin{tabular}{|c|c|c|c|c|c|c|c|c|}
\hline \multicolumn{9}{|c|}{ Panel C: Occupational distribution of individuals who dominate the median CEO } \\
\hline & & & & \multicolumn{5}{|c|}{ Size of the firm managed by the median CEO } \\
\hline & & & & $<100$ mil & $100 \mathrm{mil}-1 \mathrm{bil}$ & $1 \mathrm{bil}-10 \mathrm{bi}$ & & $>10$ bil \\
\hline \multicolumn{3}{|c|}{ Low skill } & & $20.9 \%$ & $15.0 \%$ & \multicolumn{2}{|l|}{$12.9 \%$} & $9.8 \%$ \\
\hline \multicolumn{3}{|c|}{ Medium skill } & & $20.2 \%$ & $18.2 \%$ & \multicolumn{2}{|l|}{$17.3 \%$} & $15.9 \%$ \\
\hline \multicolumn{3}{|c|}{ High skill } & & $58.9 \%$ & $66.8 \%$ & \multicolumn{2}{|l|}{$69.7 \%$} & $74.2 \%$ \\
\hline \multicolumn{3}{|c|}{ Management } & & $23.7 \%$ & $28.9 \%$ & \multicolumn{2}{|l|}{$30.9 \%$} & $33.4 \%$ \\
\hline \multicolumn{3}{|c|}{ IT } & & $7.7 \%$ & $7.7 \%$ & \multicolumn{2}{|l|}{$7.6 \%$} & $7.6 \%$ \\
\hline \multicolumn{3}{|c|}{ Engineering } & & $6.3 \%$ & $6.6 \%$ & \multicolumn{2}{|l|}{$6.6 \%$} & $6.6 \%$ \\
\hline \multicolumn{3}{|c|}{ Teaching } & & $5.9 \%$ & $6.1 \%$ & \multicolumn{2}{|l|}{$6.2 \%$} & $6.5 \%$ \\
\hline \multicolumn{3}{|c|}{ Business } & & $4.3 \%$ & $4.6 \%$ & \multicolumn{2}{|l|}{$4.8 \%$} & $5.0 \%$ \\
\hline \multicolumn{3}{|c|}{ Medicine } & & $2.4 \%$ & $3.2 \%$ & \multicolumn{2}{|l|}{$3.6 \%$} & $4.6 \%$ \\
\hline \multicolumn{3}{|c|}{ Military } & & $2.4 \%$ & $2.9 \%$ & \multicolumn{2}{|l|}{$3.1 \%$} & $3.4 \%$ \\
\hline \multicolumn{3}{|c|}{ Law } & & $0.9 \%$ & $1.1 \%$ & \multicolumn{2}{|l|}{$1.1 \%$} & $1.2 \%$ \\
\hline \multicolumn{3}{|c|}{ Other } & & $5.4 \%$ & $5.6 \%$ & \multicolumn{2}{|l|}{$5.8 \%$} & $5.9 \%$ \\
\hline \multicolumn{3}{|l|}{ Total } & & $100.0 \%$ & $100.0 \%$ & \multicolumn{2}{|l|}{$100.0 \%$} & $100.0 \%$ \\
\hline \multicolumn{3}{|c|}{ Number of individuals } & & 275,624 & 143,286 & \multicolumn{2}{|l|}{103,690} & 53,927 \\
\hline \multicolumn{9}{|c|}{ Panel D: Fraction of population dominated by CEOs' labor income, by firm size, and by family firm status } \\
\hline & & CEOs b & firm size & & & EOs by family $\mathrm{f}$ & firm stat & \\
\hline & $<100$ mil & $\begin{array}{c}100 \mathrm{mil}- \\
1 \mathrm{bil}\end{array}$ & $\begin{array}{c}1 \text { bil }-10 \\
\text { bil }\end{array}$ & $>10$ bil & $\begin{array}{l}\text { Non- } \\
\text { family }\end{array}$ & $\begin{array}{l}\text { Family, } \\
\text { external }\end{array}$ & $\begin{array}{l}\text { Family, } \\
\text { founder }\end{array}$ & $\begin{array}{c}\text { Family, } \\
\text { heir }\end{array}$ \\
\hline $5 \%$ & $22.8 \%$ & $85.5 \%$ & $96.1 \%$ & $98.8 \%$ & $26.8 \%$ & $32.6 \%$ & $21.2 \%$ & $22.8 \%$ \\
\hline $25 \%$ & $67.7 \%$ & $96.7 \%$ & $99.3 \%$ & $99.7 \%$ & $80.5 \%$ & $77.2 \%$ & $57.5 \%$ & $65.4 \%$ \\
\hline $50 \%$ & $86.9 \%$ & $98.8 \%$ & $99.8 \%$ & $99.9 \%$ & $93.9 \%$ & $91.6 \%$ & $79.3 \%$ & $82.8 \%$ \\
\hline $75 \%$ & $95.2 \%$ & $99.6 \%$ & $99.9 \%$ & $99.98 \%$ & $98.4 \%$ & $97.1 \%$ & $90.7 \%$ & $92.2 \%$ \\
\hline $90 \%$ & $98.3 \%$ & $99.8 \%$ & $99.97 \%$ & $99.997 \%$ & $99.6 \%$ & $99.2 \%$ & $95.8 \%$ & $96.6 \%$ \\
\hline $95 \%$ & $99.1 \%$ & $99.9 \%$ & $99.99 \%$ & $99.999 \%$ & $99.8 \%$ & $99.6 \%$ & $97.7 \%$ & $98.1 \%$ \\
\hline $100 \%$ & $100.0 \%$ & $100.0 \%$ & $100.0 \%$ & $100.0 \%$ & $100.0 \%$ & $100.0 \%$ & $100.0 \%$ & $100.0 \%$ \\
\hline
\end{tabular}




\section{Table 6}

\section{Pay premium of CEOs and other professions}

This table estimates the pay premiums of CEOs, medical doctors, lawyers, and engineers relative to the population. The dependent variable is the logged taxable labor income that captures base salaries, bonus payments, stock option grants, and benefits awarded to an individual in a given year. Individuals with no taxable labor income are not included in the regression. Column 1 includes dummies for CEOs in different firm-size categories and for medical doctors, lawyers, and engineers, and dummies for year and enlistment year. Column 2 includes the standardized values of cognitive and non-cognitive ability, and height. Column 3 adds dummies for five levels and eight fields of education and column 4 adds fixed effects for brothers who are born to the same mother. The $t$-values reported in parentheses are based on standard errors that allow for clustering at the individual level in all but the family fixed effects specifications where the clustering is at the level of the family.

\begin{tabular}{|c|c|c|c|c|}
\hline \multirow{2}{*}{$\begin{array}{l}\text { Dependent variable } \\
\text { Specification }\end{array}$} & \multicolumn{4}{|c|}{ Logged income } \\
\hline & 1 & 2 & 3 & 4 \\
\hline \multirow{2}{*}{ CEO dummy, $<100 \mathrm{mil}$} & 0.599 & 0.491 & 0.463 & 0.282 \\
\hline & $(159.22)$ & (133.54) & (127.89) & $(52.49)$ \\
\hline \multirow[t]{2}{*}{$\ldots 100$ mil -1 bil } & 1.389 & 1.216 & 1.118 & 0.581 \\
\hline & $(126.72)$ & (112.07) & $(102.70)$ & (39.77) \\
\hline \multirow[t]{2}{*}{$\ldots 1$ bil -10 bil } & 1.960 & 1.756 & 1.617 & 0.767 \\
\hline & $(68.68)$ & $(62.36)$ & $(58.18)$ & (19.64) \\
\hline \multirow{2}{*}{$\ldots>10$ bil } & 2.522 & 2.261 & 2.098 & 0.992 \\
\hline & $(30.48)$ & $(27.98)$ & (26.59) & $(8.80)$ \\
\hline \multirow[t]{2}{*}{ Medical doctor dummy } & 0.820 & 0.618 & & \\
\hline & $(188.40)$ & $(134.69)$ & & \\
\hline \multirow[t]{2}{*}{ Lawyer dummy } & 0.627 & 0.481 & & \\
\hline & (87.74) & $(67.65)$ & & \\
\hline \multirow[t]{2}{*}{ Engineer dummy } & 0.503 & 0.352 & & \\
\hline & $(248.76)$ & $(162.24)$ & & \\
\hline \multirow[t]{2}{*}{ Cognitive ability } & & 0.094 & 0.056 & 0.068 \\
\hline & & (137.49) & (75.44) & $(34.28)$ \\
\hline \multirow[t]{2}{*}{ Non-cognitive ability } & & 0.111 & 0.103 & 0.077 \\
\hline & & $(157.23)$ & $(144.73)$ & $(42.91)$ \\
\hline \multirow[t]{2}{*}{ Height } & & 0.022 & 0.020 & 0.018 \\
\hline & & $(35.22)$ & $(32.80)$ & $(9.35)$ \\
\hline \multicolumn{5}{|l|}{ Controls } \\
\hline Year & Yes & Yes & Yes & Yes \\
\hline Enlistment year & Yes & Yes & Yes & Yes \\
\hline Education & No & No & Yes & Yes \\
\hline Family fixed effects & No & No & No & Yes \\
\hline Mean dependent variable & 12.55 & 12.55 & 12.55 & 12.55 \\
\hline Adjusted $R^{2}$ & 0.040 & 0.076 & 0.092 & 0.531 \\
\hline Number of observations & $7,765,917$ & $7,765,917$ & $7,765,917$ & $7,687,378$ \\
\hline
\end{tabular}




\section{Table IA1}

\section{Distributions of personal traits for the population, skilled professions, and CEOs}

This table reports the distribution of cognitive ability, non-cognitive ability, and height. In Panel A, the statistics are calculated separately for the population and for CEOs of firms with less than 100 million, 100 million to 1 billion, 1 billion to 10 billion, and more than 10 billion in total assets. Panel B reports the descriptive statistics for firms that are and are not family owned. The family firms are further divided into companies managed by a professional non-family $\mathrm{CEO}$, the founder, or a later-generation family member.

\begin{tabular}{|c|c|c|c|c|c|c|c|c|c|}
\hline \multicolumn{10}{|c|}{ Panel A: Population and skilled professions } \\
\hline Ability score stanines & 1 & 2 & 3 & 4 & 5 & 6 & 7 & 8 & 9 \\
\hline Height categories & & $<165 \mathrm{~cm}$ & $165-69$ & $170-74$ & $175-79$ & $180-84$ & $185-89$ & $190-94$ & $>195 \mathrm{~cm}$ \\
\hline \multicolumn{10}{|c|}{ Population } \\
\hline Cognitive ability & $3.1 \%$ & $6.7 \%$ & $10.4 \%$ & $15.0 \%$ & $22.3 \%$ & $17.3 \%$ & $13.0 \%$ & $7.9 \%$ & $4.2 \%$ \\
\hline Non-cognitive ability & $2.0 \%$ & $5.8 \%$ & $10.7 \%$ & $17.2 \%$ & $23.4 \%$ & $18.9 \%$ & $13.9 \%$ & $6.3 \%$ & $1.8 \%$ \\
\hline Height & & $1.2 \%$ & $5.5 \%$ & $17.2 \%$ & $28.7 \%$ & $27.1 \%$ & $14.6 \%$ & $4.7 \%$ & $1.0 \%$ \\
\hline \multicolumn{10}{|c|}{ Medical doctors } \\
\hline Cognitive ability & $0.1 \%$ & $0.2 \%$ & $0.5 \%$ & $1.4 \%$ & $6.5 \%$ & $13.4 \%$ & $23.2 \%$ & $26.5 \%$ & $28.1 \%$ \\
\hline Non-cognitive ability & $0.6 \%$ & $1.8 \%$ & $3.9 \%$ & $7.8 \%$ & $14.3 \%$ & $18.8 \%$ & $25.4 \%$ & $18.2 \%$ & $9.2 \%$ \\
\hline Height & & $0.4 \%$ & $2.7 \%$ & $11.8 \%$ & $26.4 \%$ & $29.6 \%$ & $20.0 \%$ & $7.1 \%$ & $2.0 \%$ \\
\hline \multicolumn{10}{|c|}{ Engineers } \\
\hline Cognitive ability & $0.1 \%$ & $0.2 \%$ & $0.8 \%$ & $2.7 \%$ & $10.5 \%$ & $17.9 \%$ & $24.8 \%$ & $23.8 \%$ & $19.3 \%$ \\
\hline Non-cognitive ability & $0.2 \%$ & $1.4 \%$ & $4.4 \%$ & $11.8 \%$ & $21.8 \%$ & $24.1 \%$ & $22.2 \%$ & $11.1 \%$ & $3.1 \%$ \\
\hline Height & & $0.6 \%$ & $3.4 \%$ & $13.4 \%$ & $26.9 \%$ & $29.2 \%$ & $18.0 \%$ & $6.7 \%$ & $1.7 \%$ \\
\hline \multicolumn{10}{|c|}{ Lawyers } \\
\hline Cognitive ability & $0.2 \%$ & $0.4 \%$ & $1.2 \%$ & $3.9 \%$ & $15.2 \%$ & $22.7 \%$ & $27.3 \%$ & $19.3 \%$ & $9.8 \%$ \\
\hline Non-cognitive ability & $0.6 \%$ & $1.7 \%$ & $4.4 \%$ & $9.3 \%$ & $16.5 \%$ & $21.9 \%$ & $25.4 \%$ & $15.3 \%$ & $4.9 \%$ \\
\hline Height & & $0.4 \%$ & $3.1 \%$ & $12.3 \%$ & $26.7 \%$ & $30.6 \%$ & $18.8 \%$ & $6.8 \%$ & $1.4 \%$ \\
\hline
\end{tabular}




\begin{tabular}{|c|c|c|c|c|c|c|c|c|c|}
\hline \multicolumn{10}{|c|}{ Panel B: CEOs by firm size } \\
\hline \multicolumn{10}{|c|}{ CEOs, $<100$ million } \\
\hline Cognitive ability & $0.4 \%$ & $1.7 \%$ & $4.6 \%$ & $9.9 \%$ & $21.9 \%$ & $22.0 \%$ & $19.7 \%$ & $13.3 \%$ & $6.6 \%$ \\
\hline Non-cognitive ability & $0.4 \%$ & $1.5 \%$ & $3.8 \%$ & $9.1 \%$ & $18.5 \%$ & $22.4 \%$ & $24.2 \%$ & $14.7 \%$ & $5.5 \%$ \\
\hline Height & & $0.6 \%$ & $3.3 \%$ & $13.5 \%$ & $27.6 \%$ & $30.1 \%$ & $17.8 \%$ & $5.8 \%$ & $1.3 \%$ \\
\hline \multicolumn{10}{|c|}{ CEOs, 100 million -1 billion } \\
\hline Cognitive ability & $0.1 \%$ & $0.3 \%$ & $1.6 \%$ & $5.3 \%$ & $16.2 \%$ & $23.1 \%$ & $24.4 \%$ & $18.5 \%$ & $10.6 \%$ \\
\hline Non-cognitive ability & $0.0 \%$ & $0.8 \%$ & $2.0 \%$ & $5.1 \%$ & $13.0 \%$ & $19.9 \%$ & $27.6 \%$ & $23.0 \%$ & $8.7 \%$ \\
\hline Height & & $0.2 \%$ & $2.1 \%$ & $10.7 \%$ & $25.9 \%$ & $29.6 \%$ & $22.2 \%$ & $7.5 \%$ & $1.9 \%$ \\
\hline \multicolumn{10}{|c|}{ CEOs, 1 billion -10 billion } \\
\hline Cognitive ability & $0.0 \%$ & $0.0 \%$ & $0.7 \%$ & $4.3 \%$ & $14.1 \%$ & $18.8 \%$ & $28.0 \%$ & $20.8 \%$ & $13.2 \%$ \\
\hline Non-cognitive ability & $0.0 \%$ & $0.4 \%$ & $1.2 \%$ & $3.4 \%$ & $11.9 \%$ & $16.2 \%$ & $30.5 \%$ & $22.8 \%$ & $13.5 \%$ \\
\hline Height & & $0.3 \%$ & $1.9 \%$ & $9.5 \%$ & $23.2 \%$ & $34.4 \%$ & $22.2 \%$ & $7.3 \%$ & $1.2 \%$ \\
\hline \multicolumn{10}{|c|}{ CEOs, $>10$ billion } \\
\hline Cognitive ability & $0.0 \%$ & $0.0 \%$ & $0.0 \%$ & $0.7 \%$ & $7.4 \%$ & $23.0 \%$ & $30.4 \%$ & $21.6 \%$ & $16.9 \%$ \\
\hline Non-cognitive ability & $0.0 \%$ & $0.0 \%$ & $0.0 \%$ & $2.7 \%$ & $6.1 \%$ & $18.2 \%$ & $20.3 \%$ & $30.4 \%$ & $22.3 \%$ \\
\hline Height & & $0.7 \%$ & $0.7 \%$ & $4.7 \%$ & $17.6 \%$ & $33.1 \%$ & $25.7 \%$ & $15.5 \%$ & $2.0 \%$ \\
\hline \multicolumn{10}{|c|}{ Panel C: CEOs by family ownership } \\
\hline \multicolumn{10}{|c|}{ CEOs, Non-family firms } \\
\hline Cognitive ability & $0.3 \%$ & $1.1 \%$ & $3.1 \%$ & $7.6 \%$ & $19.6 \%$ & $22.4 \%$ & $21.6 \%$ & $15.9 \%$ & $8.5 \%$ \\
\hline Non-cognitive ability & $0.4 \%$ & $1.2 \%$ & $3.1 \%$ & $7.3 \%$ & $15.9 \%$ & $21.7 \%$ & $25.9 \%$ & $17.7 \%$ & $6.8 \%$ \\
\hline Height & & $0.5 \%$ & $2.8 \%$ & $11.9 \%$ & $26.6 \%$ & $30.9 \%$ & $19.0 \%$ & $6.7 \%$ & $1.5 \%$ \\
\hline \multicolumn{10}{|c|}{ CEOs, Family firms, external } \\
\hline Cognitive ability & $0.1 \%$ & $1.2 \%$ & $3.7 \%$ & $9.5 \%$ & $20.2 \%$ & $22.8 \%$ & $21.2 \%$ & $14.8 \%$ & $6.6 \%$ \\
\hline Non-cognitive ability & $0.3 \%$ & $1.1 \%$ & $3.6 \%$ & $9.4 \%$ & $16.7 \%$ & $23.0 \%$ & $26.1 \%$ & $14.6 \%$ & $5.2 \%$ \\
\hline Height & & $0.6 \%$ & $3.1 \%$ & $14.0 \%$ & $26.9 \%$ & $28.9 \%$ & $18.3 \%$ & $7.0 \%$ & $1.3 \%$ \\
\hline \multicolumn{10}{|c|}{ CEOs, Family firms, founder } \\
\hline Cognitive ability & $0.4 \%$ & $2.3 \%$ & $6.5 \%$ & $12.1 \%$ & $23.7 \%$ & $20.7 \%$ & $18.4 \%$ & $10.8 \%$ & $5.1 \%$ \\
\hline Non-cognitive ability & $0.4 \%$ & $1.7 \%$ & $4.2 \%$ & $10.4 \%$ & $21.3 \%$ & $21.6 \%$ & $22.3 \%$ & $12.7 \%$ & $5.4 \%$ \\
\hline Height & & $0.5 \%$ & $3.7 \%$ & $15.1 \%$ & $28.5 \%$ & $29.0 \%$ & $17.2 \%$ & $4.8 \%$ & $1.2 \%$ \\
\hline \multicolumn{10}{|c|}{ CEOs, Family firms, heir } \\
\hline Cognitive ability & $0.8 \%$ & $2.4 \%$ & $5.5 \%$ & $12.7 \%$ & $23.6 \%$ & $23.4 \%$ & $16.7 \%$ & $9.7 \%$ & $5.2 \%$ \\
\hline Non-cognitive ability & $0.4 \%$ & $1.8 \%$ & $5.2 \%$ & $11.4 \%$ & $20.1 \%$ & $24.0 \%$ & $20.3 \%$ & $13.4 \%$ & $3.4 \%$ \\
\hline Height & & $0.6 \%$ & $3.9 \%$ & $14.9 \%$ & $28.8 \%$ & $28.3 \%$ & $17.6 \%$ & $4.9 \%$ & $0.9 \%$ \\
\hline
\end{tabular}




\section{Table IA2}

\section{Alternative trait combinations by firm size and by family ownership}

This table reports the fraction of the population that is dominated by CEOs according to their personal traits. Panel A reports the results for firms whose total assets are less than 100 million and Panel B for firms whose total assets exceed 10 billion. Panels C-F report the results for non-family firms and family firms stratified by whether the CEO is a professional CEO, the founder, or a later-generation family member. The three leftmost columns assign cognitive ability, non-cognitive ability, and height in turn a weight of zero, with the two remaining traits attaining equal weights. The multiplicative specification calculates the product of the standardized traits in which the standardized traits have been transformed to have a minimum value of one. The minimum specification uses the smallest standardized value of the three traits to rank CEOs.

\begin{tabular}{|c|c|c|c|c|c|}
\hline \multicolumn{6}{|c|}{ Panel A: $<100$ million } \\
\hline & \multicolumn{5}{|c|}{ Trait combination } \\
\hline & $0 \%-50 \%-50 \%$ & $50 \%-0 \%-50 \%$ & $50 \%-50 \%-0 \%$ & Multiplicative & Minimum \\
\hline $5 \%$ & $16.4 \%$ & $16.5 \%$ & $20.2 \%$ & $19.9 \%$ & $17.1 \%$ \\
\hline $25 \%$ & $48.4 \%$ & $44.0 \%$ & $51.4 \%$ & $51.4 \%$ & $45.4 \%$ \\
\hline $50 \%$ & $72.5 \%$ & $67.3 \%$ & $74.0 \%$ & $73.8 \%$ & $69.5 \%$ \\
\hline $75 \%$ & $88.8 \%$ & $85.0 \%$ & $89.5 \%$ & $89.3 \%$ & $87.8 \%$ \\
\hline $90 \%$ & $96.2 \%$ & $94.1 \%$ & $96.2 \%$ & $96.2 \%$ & $95.3 \%$ \\
\hline $95 \%$ & $98.2 \%$ & $97.1 \%$ & $98.4 \%$ & $98.2 \%$ & $97.9 \%$ \\
\hline $100 \%$ & $100.0 \%$ & $100.0 \%$ & $100.0 \%$ & $100.0 \%$ & $100.0 \%$ \\
\hline \multicolumn{6}{|c|}{ Panel B: $>10$ billion } \\
\hline & \multicolumn{5}{|c|}{ Trait combination } \\
\hline & $0 \%-50 \%-50 \%$ & $50 \%-0 \%-50 \%$ & $50 \%-50 \%-0 \%$ & Multiplicative & Minimum \\
\hline $5 \%$ & $50.1 \%$ & $52.6 \%$ & $57.1 \%$ & $66.0 \%$ & $46.7 \%$ \\
\hline $25 \%$ & $79.1 \%$ & $74.2 \%$ & $83.2 \%$ & $83.3 \%$ & $73.2 \%$ \\
\hline $50 \%$ & $91.0 \%$ & $86.0 \%$ & $93.6 \%$ & $93.1 \%$ & $90.5 \%$ \\
\hline $75 \%$ & $97.9 \%$ & $95.3 \%$ & $97.8 \%$ & $97.7 \%$ & $96.2 \%$ \\
\hline $90 \%$ & $99.3 \%$ & $98.4 \%$ & $99.5 \%$ & $99.5 \%$ & $99.3 \%$ \\
\hline $95 \%$ & $99.8 \%$ & $99.0 \%$ & $99.6 \%$ & $99.7 \%$ & $99.7 \%$ \\
\hline $100 \%$ & $100.0 \%$ & $100.0 \%$ & $100.0 \%$ & $100.0 \%$ & $100.0 \%$ \\
\hline \multicolumn{6}{|c|}{ Panel C: Non-family firms } \\
\hline & \multicolumn{5}{|c|}{ Trait combination } \\
\hline & $0 \%-50 \%-50 \%$ & $50 \%-0 \%-50 \%$ & $50 \%-50 \%-0 \%$ & Multiplicative & Minimum \\
\hline $5 \%$ & $19.6 \%$ & $21.0 \%$ & $24.2 \%$ & $24.8 \%$ & $20.2 \%$ \\
\hline $25 \%$ & $54.3 \%$ & $50.4 \%$ & $58.7 \%$ & $59.2 \%$ & $52.8 \%$ \\
\hline $50 \%$ & $77.0 \%$ & $72.6 \%$ & $79.9 \%$ & $79.5 \%$ & $73.4 \%$ \\
\hline $75 \%$ & $91.1 \%$ & $87.9 \%$ & $91.9 \%$ & $92.1 \%$ & $90.3 \%$ \\
\hline $90 \%$ & $97.1 \%$ & $95.5 \%$ & $97.4 \%$ & $97.2 \%$ & $96.5 \%$ \\
\hline $95 \%$ & $98.7 \%$ & $97.8 \%$ & $98.8 \%$ & $98.8 \%$ & $98.5 \%$ \\
\hline $100 \%$ & $100.0 \%$ & $100.0 \%$ & $100.0 \%$ & $100.0 \%$ & $100.0 \%$ \\
\hline
\end{tabular}




\begin{tabular}{|c|c|c|c|c|c|}
\hline \multicolumn{6}{|c|}{ Panel D: Family firms, external } \\
\hline & \multicolumn{5}{|c|}{ Trait combination } \\
\hline & $0 \%-50 \%-50 \%$ & $50 \%-0 \%-50 \%$ & $50 \%-50 \%-0 \%$ & Multiplicative & Minimum \\
\hline $5 \%$ & $17.8 \%$ & $20.5 \%$ & $22.1 \%$ & $23.7 \%$ & $20.6 \%$ \\
\hline $25 \%$ & $50.4 \%$ & $47.4 \%$ & $55.4 \%$ & $56.0 \%$ & $47.6 \%$ \\
\hline $50 \%$ & $73.4 \%$ & $68.8 \%$ & $75.7 \%$ & $76.1 \%$ & $70.3 \%$ \\
\hline $75 \%$ & $88.7 \%$ & $86.4 \%$ & $89.8 \%$ & $89.5 \%$ & $88.8 \%$ \\
\hline $90 \%$ & $96.1 \%$ & $94.4 \%$ & $96.3 \%$ & $96.3 \%$ & $96.2 \%$ \\
\hline $95 \%$ & $98.2 \%$ & $97.2 \%$ & $98.4 \%$ & $98.3 \%$ & $98.4 \%$ \\
\hline $100 \%$ & $100.0 \%$ & $99.9 \%$ & $100.0 \%$ & $100.0 \%$ & $99.9 \%$ \\
\hline \multicolumn{6}{|c|}{ Panel E: Family firms, founder } \\
\hline & \multicolumn{5}{|c|}{ Trait combination } \\
\hline & $0 \%-50 \%-50 \%$ & $50 \%-0 \%-50 \%$ & $50 \%-50 \%-0 \%$ & Multiplicative & Minimum \\
\hline $5 \%$ & $13.1 \%$ & $12.5 \%$ & $14.8 \%$ & $15.3 \%$ & $14.4 \%$ \\
\hline $25 \%$ & $42.5 \%$ & $39.4 \%$ & $44.1 \%$ & $43.4 \%$ & $40.2 \%$ \\
\hline $50 \%$ & $66.8 \%$ & $60.7 \%$ & $67.2 \%$ & $67.2 \%$ & $66.2 \%$ \\
\hline $75 \%$ & $86.1 \%$ & $81.2 \%$ & $85.9 \%$ & $85.5 \%$ & $83.0 \%$ \\
\hline $90 \%$ & $95.0 \%$ & $91.6 \%$ & $95.1 \%$ & $94.7 \%$ & $94.4 \%$ \\
\hline $95 \%$ & $97.5 \%$ & $95.9 \%$ & $97.5 \%$ & $97.2 \%$ & $97.0 \%$ \\
\hline $100 \%$ & $100.0 \%$ & $100.0 \%$ & $100.0 \%$ & $100.0 \%$ & $100.0 \%$ \\
\hline \multicolumn{6}{|c|}{ Panel F: Family firms, heir } \\
\hline & \multicolumn{5}{|c|}{ Trait combination } \\
\hline & $0 \%-50 \%-50 \%$ & $50 \%-0 \%-50 \%$ & $50 \%-50 \%-0 \%$ & Multiplicative & Minimum \\
\hline $5 \%$ & $14.3 \%$ & $12.5 \%$ & $14.8 \%$ & $15.3 \%$ & $14.4 \%$ \\
\hline $25 \%$ & $44.0 \%$ & $39.4 \%$ & $44.1 \%$ & $43.4 \%$ & $40.2 \%$ \\
\hline $50 \%$ & $68.9 \%$ & $60.7 \%$ & $67.2 \%$ & $67.2 \%$ & $66.2 \%$ \\
\hline $75 \%$ & $86.6 \%$ & $81.2 \%$ & $85.9 \%$ & $85.5 \%$ & $83.0 \%$ \\
\hline $90 \%$ & $95.6 \%$ & $91.6 \%$ & $95.1 \%$ & $94.7 \%$ & $94.4 \%$ \\
\hline $95 \%$ & $97.8 \%$ & $95.9 \%$ & $97.5 \%$ & $97.2 \%$ & $97.0 \%$ \\
\hline $100 \%$ & $100.0 \%$ & $100.0 \%$ & $100.0 \%$ & $100.0 \%$ & $100.0 \%$ \\
\hline
\end{tabular}


Table IA3

Pay premiums using total income in lieu of labor income

This table estimates the pay premiums of CEOs, medical doctors, lawyers, and engineers compared to the population. The regressions follow the structure of Table 6 , but replace the dependent variable with total taxable income. The $t$ values reported in parentheses are based on standard errors that allow for clustering at the individual level in all but the family fixed effects specifications where the clustering is at the level of the family.

\begin{tabular}{|c|c|c|c|c|}
\hline \multirow{2}{*}{$\begin{array}{l}\text { Dependent variable } \\
\text { Specification }\end{array}$} & \multicolumn{4}{|c|}{ Logged income } \\
\hline & 1 & 2 & 3 & 4 \\
\hline \multirow{2}{*}{ CEO dummy, $<100 \mathrm{mil}$} & 0.750 & 0.635 & 0.605 & 0.321 \\
\hline & $(175.62)$ & $(150.91)$ & $(144.98)$ & $(57.85)$ \\
\hline \multirow[t]{2}{*}{$\ldots 100$ mil -1 bil } & 1.528 & 1.344 & 1.239 & 0.593 \\
\hline & (130.65) & $(114.85)$ & $(104.77)$ & $(39.60)$ \\
\hline \multirow[t]{2}{*}{$\ldots 1$ bil -10 bil } & 2.040 & 1.821 & 1.677 & 0.768 \\
\hline & $(65.54)$ & $(58.80)$ & $(55.22)$ & $(19.68)$ \\
\hline \multirow{2}{*}{$\ldots>10$ bil } & 2.628 & 2.348 & 2.179 & 0.970 \\
\hline & $(25.59)$ & $(23.33)$ & (21.59) & $(8.62)$ \\
\hline \multirow[t]{2}{*}{ Medical doctor dummy } & 0.813 & 0.595 & & \\
\hline & (194.72) & $(134.21)$ & & \\
\hline \multirow[t]{2}{*}{ Lawyer dummy } & 0.677 & 0.519 & & \\
\hline & $(89.70)$ & $(69.79)$ & & \\
\hline \multirow[t]{2}{*}{ Engineer dummy } & 0.501 & 0.337 & & \\
\hline & $(253.53)$ & $(159.30)$ & & \\
\hline \multirow[t]{2}{*}{ Cognitive ability } & & 0.103 & 0.065 & 0.072 \\
\hline & & $(159.73)$ & (91.48) & $(38.36)$ \\
\hline \multirow[t]{2}{*}{ Non-cognitive ability } & & 0.116 & 0.106 & 0.078 \\
\hline & & $(172.80)$ & (158.09) & $(46.36)$ \\
\hline \multirow[t]{2}{*}{ Height } & & 0.024 & 0.022 & 0.018 \\
\hline & & (41.19) & $(38.05)$ & $(10.08)$ \\
\hline \multicolumn{5}{|l|}{ Controls } \\
\hline Year & Yes & Yes & Yes & Yes \\
\hline Enlistment year & Yes & Yes & Yes & Yes \\
\hline Education & No & No & Yes & Yes \\
\hline Family fixed effects & No & No & No & Yes \\
\hline Mean dependent variable & 12.60 & 12.60 & 12.60 & 12.60 \\
\hline Adjusted $R^{2}$ & 0.050 & 0.094 & 0.110 & 0.522 \\
\hline Number of observations & $7,765,917$ & $7,765,917$ & $7,765,917$ & $7,687,378$ \\
\hline
\end{tabular}




\section{Table IA4}

\section{Pay premium of CEOs and other professions when cognitive ability subcomponents are controlled for}

This table estimates the pay premiums of CEOs, medical doctors, lawyers, and engineers relative to the population. The regressions follow the structure of Table 6 , but break down cognitive ability into its four subcomponents. The number of observations is smaller than in Table 6 because the subscores are missing for about 135,000 individuals. The $t$-values reported in parentheses are based on standard errors that allow for clustering at the individual level in all but the family fixed effects specifications where the clustering is at the level of the family.

\begin{tabular}{|c|c|c|c|c|}
\hline \multirow{2}{*}{$\begin{array}{l}\text { Dependent variable } \\
\text { Specification } \\
\end{array}$} & \multicolumn{4}{|c|}{ Logged income } \\
\hline & 1 & 2 & 3 & 4 \\
\hline \multirow[t]{2}{*}{ CEO dummy, $<100 \mathrm{mil}$} & 0.601 & 0.489 & 0.460 & 0.279 \\
\hline & (154.10) & (128.70) & (123.00) & (49.55) \\
\hline \multirow[t]{2}{*}{$\ldots 100$ mil -1 bil } & 1.389 & 1.204 & 1.101 & 0.568 \\
\hline & $(124.58)$ & $(109.71)$ & (99.52) & (38.06) \\
\hline \multirow[t]{2}{*}{$\ldots 1$ bil -10 bil } & 1.965 & 1.744 & 1.598 & 0.754 \\
\hline & $(67.56)$ & $(61.07)$ & $(56.48)$ & (19.25) \\
\hline \multirow[t]{2}{*}{$\ldots>10$ bil } & 2.519 & 2.246 & 2.076 & 0.981 \\
\hline & $(30.25)$ & $(27.61)$ & (26.14) & (8.58) \\
\hline \multirow[t]{2}{*}{ Medical doctor dummy } & 0.843 & 0.622 & & \\
\hline & $(182.36)$ & $(127.67)$ & & \\
\hline \multirow[t]{2}{*}{ Lawyer dummy } & 0.643 & 0.476 & & \\
\hline & $(81.36)$ & $(60.72)$ & & \\
\hline \multirow[t]{2}{*}{ Engineer dummy } & 0.506 & 0.344 & & \\
\hline & $(223.38)$ & $(142.58)$ & & \\
\hline \multirow[t]{2}{*}{ Induction } & & 0.074 & 0.052 & 0.049 \\
\hline & & $(74.42)$ & $(51.67)$ & (19.31) \\
\hline \multirow[t]{2}{*}{ Verbal } & & 0.024 & 0.011 & 0.015 \\
\hline & & $(25.48)$ & (11.43) & $(6.50)$ \\
\hline \multirow[t]{2}{*}{ Spatial } & & 0.005 & -0.001 & 0.002 \\
\hline & & $(6.30)$ & $(-1.63)$ & (1.12) \\
\hline \multirow[t]{2}{*}{ Technical } & & 0.020 & 0.012 & 0.024 \\
\hline & & $(23.14)$ & (13.66) & $(10.85)$ \\
\hline \multirow[t]{2}{*}{ Non-cognitive ability } & & 0.106 & 0.098 & 0.074 \\
\hline & & (139.44) & $(128.72)$ & $(37.25)$ \\
\hline \multirow[t]{2}{*}{ Height } & & 0.021 & 0.019 & 0.017 \\
\hline & & $(32.00)$ & $(29.47)$ & $(8.07)$ \\
\hline \multicolumn{5}{|l|}{ Controls } \\
\hline Year & Yes & Yes & Yes & Yes \\
\hline Enlistment year & Yes & Yes & Yes & Yes \\
\hline Education & No & No & Yes & Yes \\
\hline Family fixed effects & No & No & No & Yes \\
\hline Mean dependent variable & 12.57 & 12.57 & 12.57 & 12.57 \\
\hline Adjusted $R^{2}$ & 0.035 & 0.074 & 0.093 & 0.549 \\
\hline Number of observations & $6,815,471$ & $6,815,471$ & $6,815,471$ & $6,744,952$ \\
\hline
\end{tabular}




\section{Table IA5}

\section{Additional traits}

Panel A reports means, medians, and standard deviations of cardiovascular fitness and muscle strength for the population, skilled professions, and for CEOs. The statistics for CEOs are calculated separately by firm size and by family firm status. Panel B builds on the regression in Table 4 Panel A by regressing the dummy for CEOs on standardized values of cardiovascular fitness, muscle strength, cognitive and non-cognitive ability, and height. Cardiovascular fitness is measured in a cycle ergometry test and muscle strength in a combination of knee extension, elbow flexion, and hand grip tests. The number of observations is smaller in the specifications including muscle strength because this variable is missing for about 150,000 individuals. The $t$-values reported in parentheses are based on standard errors that allow for clustering at the individual level. The mean dependent variable and the coefficients are multiplied by one hundred.

\begin{tabular}{|c|c|c|c|}
\hline \multicolumn{4}{|c|}{ Panel A: Descriptive statistics } \\
\hline & & Cardiovascular fitness & Muscle strength \\
\hline \multirow[t]{3}{*}{ Population } & Mean & 6.26 & 5.65 \\
\hline & $\mathrm{Sd}$ & 1.71 & 1.90 \\
\hline & Median & 6 & 5 \\
\hline \multirow[t]{3}{*}{ Medical doctors } & Mean & 7.10 & 5.96 \\
\hline & $\mathrm{Sd}$ & 1.67 & 1.87 \\
\hline & Median & 7 & 6 \\
\hline \multirow[t]{3}{*}{ Engineers } & Mean & 6.80 & 5.91 \\
\hline & $\mathrm{Sd}$ & 1.60 & 1.82 \\
\hline & Median & 6 & 6 \\
\hline \multirow[t]{3}{*}{ Lawyers } & Mean & 6.78 & 5.98 \\
\hline & $\mathrm{Sd}$ & 1.63 & 1.88 \\
\hline & Median & 6 & 6 \\
\hline \multirow[t]{3}{*}{ CEOs, $<100$ million } & Mean & 6.77 & 5.98 \\
\hline & $\mathrm{Sd}$ & 1.71 & 1.88 \\
\hline & Median & 7 & 6 \\
\hline \multirow[t]{3}{*}{ CEOs, 100 million -1 billion } & Mean & 7.16 & 5.93 \\
\hline & $\mathrm{Sd}$ & 1.65 & 1.87 \\
\hline & Median & 7 & 6 \\
\hline \multirow[t]{3}{*}{ CEOs, 1 billion -10 billion } & Mean & 7.38 & 5.86 \\
\hline & $\mathrm{Sd}$ & 1.64 & 1.87 \\
\hline & Median & 8 & 6 \\
\hline \multirow[t]{3}{*}{ CEOs, $>10$ billion } & Mean & 7.47 & 5.75 \\
\hline & $\mathrm{Sd}$ & 1.58 & 1.83 \\
\hline & Median & 8 & 5 \\
\hline \multirow[t]{3}{*}{ CEOs, non-family firms } & Mean & 6.92 & 5.96 \\
\hline & $\mathrm{Sd}$ & 1.70 & 1.87 \\
\hline & Median & 7 & 6 \\
\hline \multirow[t]{3}{*}{ CEOs, family firms, external } & Mean & 6.83 & 5.91 \\
\hline & $\mathrm{Sd}$ & 1.71 & 1.82 \\
\hline & Median & 7 & 6 \\
\hline \multirow[t]{3}{*}{ CEOs, family firms, founder } & Mean & 6.50 & 6.02 \\
\hline & $\mathrm{Sd}$ & 1.69 & 1.89 \\
\hline & Median & 6 & 6 \\
\hline \multirow[t]{3}{*}{ CEOs, family firms, heir } & Mean & 6.70 & 5.99 \\
\hline & $\mathrm{Sd}$ & 1.73 & 1.89 \\
\hline & Median & 7 & 6 \\
\hline
\end{tabular}




\begin{tabular}{|c|c|c|c|c|c|c|}
\hline \multicolumn{7}{|c|}{ Panel B: Regressions } \\
\hline Dependent variable & & & $\mathrm{CEC}$ & ummy & & \\
\hline Specification & 1 & 2 & 3 & 4 & 5 & 6 \\
\hline Cardiovascular fitness & $\begin{array}{r}0.363 \\
(42.48)\end{array}$ & $\begin{array}{c}0.041 \\
(4.47)\end{array}$ & $\begin{array}{c}0.024 \\
(2.63)\end{array}$ & & & \\
\hline Muscle strength & & & & $\begin{array}{r}0.462 \\
(43.00)\end{array}$ & $\begin{array}{c}0.010 \\
(0.80)\end{array}$ & $\begin{array}{l}-0.008 \\
(-0.65)\end{array}$ \\
\hline Cognitive ability & & $\begin{array}{r}0.306 \\
(38.34)\end{array}$ & $\begin{array}{r}0.227 \\
(24.95)\end{array}$ & & $\begin{array}{r}0.284 \\
(33.58)\end{array}$ & $\begin{array}{r}0.214 \\
(22.19)\end{array}$ \\
\hline Non-cognitive ability & & $\begin{array}{r}0.575 \\
(59.25)\end{array}$ & $\begin{array}{r}0.543 \\
(55.99)\end{array}$ & & $\begin{array}{r}0.610 \\
(57.12)\end{array}$ & $\begin{array}{r}0.577 \\
(53.99)\end{array}$ \\
\hline Height & & $\begin{array}{r}0.117 \\
(14.98)\end{array}$ & $\begin{array}{r}0.110 \\
(14.01)\end{array}$ & & $\begin{array}{r}0.114 \\
(13.26)\end{array}$ & $\begin{array}{r}0.108 \\
(12.60)\end{array}$ \\
\hline Controls & & & & & & \\
\hline Year & Yes & Yes & Yes & Yes & Yes & Yes \\
\hline Enlistment year & Yes & Yes & Yes & Yes & Yes & Yes \\
\hline Education & No & No & Yes & No & No & Yes \\
\hline Mean dependent variable & 1.113 & 1.113 & 1.113 & 1.097 & 1.097 & 1.097 \\
\hline Adjusted $R^{2}$ & 0.003 & 0.007 & 0.010 & 0.003 & 0.007 & 0.011 \\
\hline Number of observations & $8,760,402$ & $8,760,402$ & $8,760,402$ & $7,665,250$ & $7,665,250$ & $7,665,250$ \\
\hline
\end{tabular}

